\title{
SUBURBAN ZONING AND THE APARTMENT BOOM
}

\section{Richard F. Babcock $\nmid$ and Fred P. Bosselman $\ddagger$}

No greater contribution could be made to the stability of the Nation, and the advancement of its ideals, than to make it a nation of home-owning families.

\section{Apartment houses are not inherently benign. ${ }^{2}$}

The dominant single-family dwelling pattern of most suburban communities faces a major challenge. The homogeneous suburb, having endured the attacks of its social critics, faces a far more formidable opponent in the developer who sees an opportunity to profit from the construction of apartment buildings outside the central city. During the decade of the sixties, there will be unprecedented pressure to permit construction in suburban areas of multiple-family units, varying widely in type and design. The suburbs will kick and scream, and the ensuing series of bitter political and legal struggles will confront the supreme courts of the more populous states with such a multitude of zoning cases as to displace-at last-the ubiquitous gas station. ${ }^{3}$

It is the purpose of this Article to examine the historic and current legal status of the multiple-family dwelling, the reasons for the increased pressure for apartments outside the metropolitan area, and the reaction of suburban communities to this pressure. An attempt will also be made to point out the difficult questions which must be answered before a rational and socially useful settlement of the dispute can be achieved.

\section{Early Regulation of Multiple-Family Dwellings}

Attempts to regulate multiple-family dwellings are almost as old as multiple-family dwellings themselves. Lewis Mumford has called

$\dagger$ A.B. 1940, Dartmouth College; J.D. 1946, M.B.A. 1951, University of Chicago. Member, Illinois Bar.

$\$$ A.B. 1956, University of Colorado; LL.B. 1959, Harvard University. Member, Illinois Bar.

1 President Calvin Coolidge, quoted in Building Age, May 1925, p. 103.

2 Fanale v. Borough of Hasbrouck Heights, 26 N.J. 320, 325, 139 A.2d 749, 752 (1958).

3 Gasoline stations have traditionally been the most prolific source of zoning litigation. A recent annotation of gas station cases ran to 143 pages. See Annot., 75 A.L.R.2d 168 (1961). 
Nero's fire a "systematic slum clearance project" " which destroyed some of the forty-six thousand tenement houses in Rome." In this country, however, the multiple-family dwelling as we know it today was born in the $1830^{\prime} \mathrm{s}^{6}$ at the time of the first great influx of immigrants into our urban areas. ${ }^{7}$ This flood of workers needed housing close to their places of employment, which at that time were primarily concentrated in the larger cities. ${ }^{8}$ Most of the immigrants were poor laborers, accustomed to crowded housing on the "teeming shores" of Europe; ${ }^{10}$ they had no aspirations for luxury housing. Economic conditions called for inexpensive housing for large numbers of people. ${ }^{11}$

With the construction techniques available at the time, the most economical housing was a type of multiple-family dwelling which came to be known as the tenement. ${ }^{12}$ The picture of tenement life is, by now, a familiar one. Mumford's description is concise, but accurate: "[The tenement] covered ninety percent of the lot and standardized airless and insanitary conditions." 13 In the more crowded areas, party walls, shared by adjacent buildings, were the rule, rather than the exception. ${ }^{14}$ In a typical tenement, separate dwelling units were built along the length of a narrow lot, with only one unit fronting on the

4 MUArford, The CITY IN History 220 (1961). It should hardly be necessary to add that Mumford is being facetious, except that there are some people today who think that the best way to "regulate" multiple-family dwellings is not to have any.

5 Id. at 219.

6 Many of the earliest multiple-family dwellings were converted single-family houses. The first large scale tenements constructed solely for that purpose appeared about 1850. TunNard \& Reed, AMrerican Skyline 98-100 (Mentor ed. 1956).

7 Hansen, The Atlantic Migration 1607-1860, at 172 (1951); Mumford, op. cit. supra note 4, at 433; RodwIN, HousING AND ECoNoMrc Progress 88, 90 (1961); Claghorn, Foreign Immigration and the Tenement House in New York City, in 2 The Tenement House Problem 65 (DeForest \& Veiller eds. 1903).

8 Handrin, The Uprooted 63 (1951); $c f$. Vernon, The Myth and Reality of OUR URBAN PROBLEMS 21 (1961).

9 Handlin, Boston's Immigrants 250-51 (rev. ed. 1959) ; Hansen, The AtLANTIC MIGRATION 1607-1860, at 242-53 (1951).

10 See generally Bauer, Modera Housing 3-23 (1934).

11 "The people came down on the towns like the proverbial Assyrians, except that as it turned out they were rather the sheep than the wolves of the story." BAUER, MODERN HOUSING 12 (1934).

12 "TENEMENT House, a multiple dwelling arranged for the occupation of several families, each of which can live independently and do its cooking within its apartment." 26 THE ENCYCLOPEDIA AMERICANA 413 (10th ed. 1937).

13 MUArFoRd, oṕ. cit. supra note 4 , at 433.

14 See Schultz v. Wireman, 4 Phila. 121, 123 (Pa. C.P. 1860), in which the court, in upholding a law requiring side yards, said:

Philadelphia had not been without her warning upon this subject, and the public demanded legislative protection against the folly and cupidity of men, who would build houses that could only be kept standing upon the principle of association, or combination; each leaning upon the other for support 
street. $^{15}$ The interior units, when not windowless, abutted only on a narrow court or alleyway. ${ }^{16}$ The buildings were usually constructed of wood,,$^{17}$ and fires were frequent. ${ }^{18}$ No interior plumbing of any type was provided. ${ }^{19}$

An 1884 Pennsylvania case ${ }^{20}$ provides a typical example. Plaintiff sought permission to develop a 40 -foot lot as shown in the following diagram: ${ }^{21}$

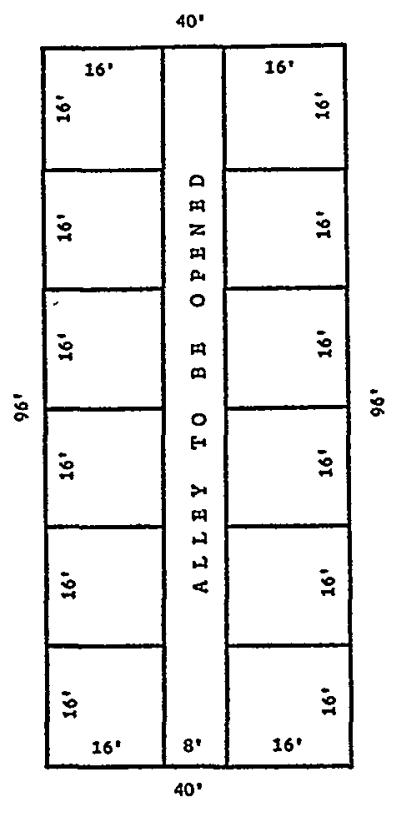

S TRERT

Each of the twelve dwelling units was to be sixteen feet square and three stories tall, with an interior stairway. The units were to contain

15 See, e.g., Singer v. City of Philadelphia, $112 \mathrm{~Pa} .410,4$ Atl. 28 (1886) ; Schultz v. Doak, 4 Phila. 151 (Pa. C.P. 1860). See also AbBott, The TENEMENTS of Chrcago 1908-1935, at 190-97 (1936); RIIS, How the Other Half Lives (rev. ed. 1957); Veiller, Back to Back Tenements, in 1 The Tenement House Problem 291 (DeForest \& Veiller eds. 1903).

18 See, e.g., Brice's Appeal, 89 Pa. 85 (1879).

17 See Aввотт, op. cit. supra note 15, at 184-90 (1936). Building materials varied in different parts of the country.

18 Bonnver \& Veiller, Tenement House Fires in New York, in 1 The TENEMENT House Problem 261 (DeForest \& Veiller eds. 1903). See RIIs, A Ten Years' War 39-42 (1900).

19 TunNard \& REed, op. cit. supra note 6, at 100; Webster, Tenement Honse Sanitation, in 1 The Tenement House Problem 301 (DeForest \& Veiller eds. 1903).

20 Eichel v. Zimmerman, 17 Phila. 290 (Pa. C.P. 1884).

21 The diagram, drawn by the authors, is based on the facts stated in the case. 
no water or plumbing. Occupancy of this type of housing can only be compared to life in an elevator shaft. ${ }^{22}$

The unhealthful aspects of tenement life are well known-disease was prevalent, ${ }^{23}$ and unpleasant odors predominated. ${ }^{24}$ Nevertheless, property values in tenement neighborhoods were high, inducing land owners to continue to construct buildings which would accommodate the maximum number of families per square foot. ${ }^{25}$

Public displeasure with conditions in tenement neighborhoods compelled state and local legislatures to pass laws regulating the construction and, to some extent, the operation of tenements. ${ }^{26}$ It is important to understand that most of these early laws were not housing laws-that is, they did not include general regulations governing housing. They were directed at a particular evil, the syndrome of social conditions which was outwardly symbolized by the tenement. ${ }^{27}$

Today these early laws seem very mild. ${ }^{28} \mathrm{~A}$ minimum amount of light, air, and open space was required for occupants of new

22 Perhaps things were worse in New York. Catherine Bauer has described the early New York tenements as follows:

The buildings are twenty-five feet wide and about ninety feet deep on a twenty-five by one-hundred foot lot. They are five to seven stories high and there are four dwellings per floor, containing all together two rooms looking on the street, two on a ten-foot rear court, and ten to twelve interior rooms, sometimes with tiny air-shafts, but often without windows of any sort.

Bauer, Modern Housing 15-16 (1934). But see Wood, The Housing of the UNSKIILED WAGE EARNER 57 (1919), in which the author comments that "such tenements as Philadelphia has are more neglected and objectionable than those of New York." The style of construction of tenements varied from city to city, but the resulting environment was everywhere remarkably similar. See TUNNARD \& REED, op. cit. supra note 6 , at 100 .

23 See Abraiss, The Future of Housing 23, 29-31 (1946); RIIs, How the OTHER HALF ITVES 47, 229-30 (rev. ed. 1957); Schulman, Honsing Legislation in Pennsylvania, 13 Temp. L.Q. 166, 169-73 (1939).

$24 \mathrm{~A}$ curious thing about Philadelphia is that pigs were permitted to be kept in the thickly settled parts of the city until quite recently. A start was made to do away with this condition, the 40,000 piggeries of a few years ago having been reduced to about 10,000 by the spring of 1917 , when the Health Department at last decreed that all must go.

Wood, op. cit. supra note 22, at 56; see Paris v. Philadelphia, $63 \mathrm{~Pa}$. Super. 41 (1916). 25 Gould, Financial Aspects of Recent Tenement House Operations in New York, in 1 The Tenement House Problem 355 (DeForest \& Veiller eds. 1903); see Bauter, Modern Housing 12-18 (1934); cf. Mumpord, op. cit. supra note 4, at 220.

26 See Veiller, Housing Conditions and Tenement Laws in Leading American Cities, in 1 The Tenement House Problem 129 (DeForest \& Veiller eds. 1903).

27 Most fire and health regulations were specifically made applicable only to tenement areas, and not to the rest of the city's housing. See $\mathrm{Pa}$. Laws 1895, Act 110 , at 178; 2 Dimlon, MUNICIPAL Corporatrons $\$ 698$ (5th ed. 1911); BaSSETT, ZoNING 22 (1936) ; Fisher, Housing Legislation and Housing Policy in the United States, 31 MICH. L. REv. 320, 328-29 (1933). The continued existence of "fire limits" is a vestige of these regulations.

To some early courts, the fact that a law regulated all housing and not just tenements was a strike against it. See, e.g., Commonwealth v. Corson, $36 \mathrm{~Pa}$. Super. 7 (1908).

28 For examples of the stringency of modern housing codes compared to the early building laws see, e.g., Queenside Hills Realty Co. v. Saxl, 328 U.S. 80 (1946); Kaukas v. City of Chicago, 27 IIl. 2d 197, 188 N.E.2d 700 (1963). 
tenements. ${ }^{29}$ But the primary motive was to restrain the disastrous fires which frequently tore through tenement areas, destroying property values as well as lives. ${ }^{30}$ An attempt was usually made, therefore, to regulate the materials employed in the construction of tenement buildings, generally restricting the use of wood. ${ }^{31}$

In an era when the law tended to look with disfavor upon any restrictions on the use of private property, and particularly real property, the courts, when confronted with these new regulations, were forced to balance some very delicate social and moral questions. Out of this process developed two highly important judicial attitudes. First, the courts became acquainted with the worst type of multiple-family housing. The cases that reached the courts usually involved tenements of the most dangerous and unsavory character, because the better apartments avoided litigation. Consequently, multiple-family housing developed an extremely bad reputation in the courts-a reputation that persists today even though the type and design of multiple-family housing have changed radically. Second, the courts did authorize the treatment of multiple-family dwellings as a separate category from single-family dwellings. ${ }^{32}$ This distinction, which today may appear anomalous, is easily understood when viewed in historical perspective. The tenements housed a distinct and separate class of people-the new immigrants-with whom the mid-nineteenth century judge felt little kinship. While to the immigrant the tenement was "home," to the landlord it was a piece of income-producing real estate; only the

${ }^{29}$ E.g., Pa. Laws 1855, Act 496, at 464. See Wood, $A$ Century of the Housing Problem, 1 LAW \& ConteMP. Prob. 137, 138-39 (1934).

For examples of how little benefit was received from the earliest New York regulations see TUNNARD \& REED, op, cit. supra note 6 , at 133 ; RIIS, THE PERII AND the Preservation of the HoNe 127 (1903).

30 "The regulation in question is a measure for the general benefit. It adds to the value of property by lessening the hazard from fire, which operates as a tax upon it . " Wadleigh v. Gilman, $12 \mathrm{Me}$. 403, 405 (1835). See also Ex parte Fiske, 72 Cal. 125, 13 Pac. 310 (1887); City of Salem v. Maynes, 123 Mass. 372 (1877); Eichenlaub v. City of St. Joseph, 113 Mo. 395, 21 S.W. 8 (1893); Schulman, supra note 23 , at 174 .

31 In Kneedler v. Borough of Norristown, $100 \mathrm{~Pa} .368,372-73$ (1882), the court struck down an ordinance which prohibited the erection of wooden buildings in any part of the town.

[I]t could not be tolerated that the people . . should be absolutely prohibited by the vote of a transient majority of their councils, from using such material in the construction of their dwellings, their shops, stores, factories and outbuildings. It would be a grievance too intolerable to be borne.

But see Respublica v. Duquet, 2 Yeates 493 (Pa. Sup. Ct. 1799); Klingler v. Bickel, $117 \mathrm{~Pa} .326,11$ Atl. 555 (1887), in which ordinances prohibiting wooden buildings only in tenement areas were upheld.

32 Toward the end of the nineteenth century, the regulations condoned by the Massachusetts court became so stringent that construction of new housing for the lowest income groups virtually ceased. RoDwin, Housing aNd Economic Progress 90 (1961). But as late as 1880, the Pennsylvania Supreme Court struck down a law requiring indoor plumbing. Philadelphia v. Provident Trust Co., $132 \mathrm{~Pa} .224$, 18 Atl. 1114 (1880). But see Health Dep't v. Trinity Church, 145 N.Y. 32, 39 N.E. 833 (1895). 
single-family house was home. The judges absorbed the landlords' viewpoint.

Early zoning law developed against this background of tenement regulation. The early height and bulk restrictions, designed to give light and air to multiple-family neighborhoods, were little more than expanded versions of the early tenement laws. ${ }^{33}$ Although some attempt was made to alleviate the symptoms of tenement life, a far more important goal was cure of the tenement disease by the prevention of its spread. ${ }^{34}$ In a society wedded to laissez faire, there was little hope of seriously improving the life of the poor through governmental action. ${ }^{35}$ But the rules of laissez faire, like the fur of a cat, feel much different when you start at the head and rub down than when you start at the tail and rub up. Interference with the landlord's right to divide his tenement into airless cubicles was considered quite presumptious, ${ }^{36}$ but few moral qualms were caused by limitations on the right to infect single-family neighborhoods by the construction of tenements. ${ }^{37}$

In light of this background, it is odd that the drafters of the 1916 New York City zoning ordinance did not establish separate districts for various housing types. ${ }^{38}$ It is possible that they had some doubts as to the legal validity of excluding multiple-family dwellings from singlefamily neighborhoods. ${ }^{39}$ If so, their anxiety was unwarranted. The state courts, familiar with tenement problems and with the earlier regulatory legislation which had classified tenements as a separate group, had very little trouble justifying this separate classification. ${ }^{40}$ It is more likely, therefore, that this issue was of no concern to the drafters, charged as they were with finding some rational and legal means by which to protect Fifth Avenue shops from the spread of the Seventh Avenue garment district. ${ }^{41}$

33 See Williams, The Law of City Planning and Zoning 198 (1922).

34 Wood, supra note 29, at 139; see WeBER, THE Growth of Citres IN THE Nineteenth Century 457-59 (1899).

35 A committee of the Philadelphia Medical Society euphemistically recommended in 1832 that "the dwellings of the poor should be thoroughly cleaned and whitewashed at public expense." Schulman, supra note 23, at 170 n.17.

36 See, e.g., Brice's Appeal, $89 \mathrm{~Pa} .85$ (1879), in which the court said that as long as the landlord maintained locked doors separating the rooms of his building, he could not be prevented from leasing separate rooms to individual tenants.

37 See, e.g., Brett v. Building Comm'r, 250 Mass. 73, 145 N.E. 269 (1924);

Delano v. City of Tulsa, 26 F.2d 640 (8th Cir.), cert. denied, 278 U.S. 654 (1928). 38 See WrlliaMs, op. cit. supra note 33 , at 268.

39 BasseTT, ZoNIng 63-64, 192-93 (1940); WIILIAMs, op. cit. supra note 33, at 273-75, 291-92.

40 The first single-family zone apparently was enacted by Los Angeles in 1920. Whitnall, History of Zoning, 155 Annals, pt. 2, pp. 1, 12 (May 1931); see Miller v. Board of Public Works, 195 Cal. 477, 234 Pac. 381 (1925).

41 Whitnall, supra note 40, at 11; see Williams, Planning Laze and the Supreme Court, 13 ZoNINg Digest 57 n.71 (1961). 
Many of the state court opinions dealing with the early zoning ordinances, however, did involve conflicts between apartment builders and single-family zones. ${ }^{42}$ The authors of these opinions showed a great familiarity with the typical tenement of the earlier cases. They characterized multiple-family housing as productive of congestion, ${ }^{43}$ fire, ${ }^{44}$ dirt $^{45}$ noise, ${ }^{46}$ and disease, ${ }^{47}$ stereotyping all multiple-family housing with the defects of the worst.

The courts also found that multiple-family housing contributed to crime ${ }^{48}$ and, indeed, to lower moral standards. "The number of people passing in and out [of tenements] render immoral practices therein more difficult of detection and suppression." 49 Single-family housing, however, was romanticized as contributing to patriotism, and exemplifying in every respect the American way of life. ${ }^{50}$ The opinion of the California Supreme Court upholding an ordinance prohibiting the construction of any building "designed or intended to be used for the housing of more than two families," is typical.

42 See, e.g., Minkus v. Pond, 326 IIl. 467, 158 N.E. 121 (1927).

43 See Wolfsohn v. Burden, 241 N.Y. 288, 297-98, 150 N.E. 120, 123 (1925); City of Jackson v. McPherson, 162 Miss. 164, 176, 138 So. 604, 605 (1932).

44 See Brett v. Building Comm'r, 250 Mass. 73, 145 N.E. 269 (1924); City of Bismarck v. Hughes, 53 N.D. 838, 851, 208 N.W. 711, 716 (1926).

45 See Kennedy v. City of Evanston, 348 I11. 426, 432, 181 N.E. 312, 314 (1932).

46 See Rice v. Van Vranken, 132 Misc. 82, 86, 229 N.Y. Supp. 32, 37 (Sup. Ct. 1928), aff'd, 225 App. Div. 179, 232 N.Y. Supp. 506 (1929), aff'd mem., 255 N.Y. 541, 175 N.E. 304 (1930); State ex rel. Morris v. Osborn, 22 Ohio N.P. (n.s.) 549, 554-55 (C.P. 1920).

In modern suburban garden apartments, noise continues to be the most common tenant complaint. See The Nagging Problem of Noise, House \& Home, Feb. 1963, p. 98 .

47 See Wolfsohn v. Burden, 241 N.Y. 288, 297-98, 150 N.E. 120, 122 (1925); Pritz v. Messer, 112 Ohio St. 628, 643-45, 149 N.E. 30, 35 (1925) ; City of Providence v. Stephens, 47 R.I. 387, 133 Atl. 614, 617 (1926).

48 "The breaking up of the home and the raising of children in hotels, apartment houses, and upon the streets is responsible for the great increase in the delinquency among children and for the increases in crime." City of Bismarck v. Hughes, 53 N.D. $838,851-52,208$ N.W. 711,716 (1926).

49 State ex rel. Morris v. Osborn, 22 Ohio N.P. (n.s.) $549,554-55$ (C.P. 1920). But see E \& M Land Co. v. Board of Adjustment, 4 N.J. Misc. 467, 469, 133 AtI. 413, 414 (Sup. Ct. 1926), aff'd per curiam, 103 N.J.L. 487, 135 Atl. 916 (Ct. Err. \& App. 1927). For an amusing discussion in the Victorian tradition see Reynolds, Prostitution as a Tenement House Evil, in 2 The Tenement House Problem 15 (DeForest \& Veillers eds. 1903).

The modern attitude toward motels, exemplified in Alinder v. City of Homewood, 254 Ala. 525, 49 So. 2d 108 (1950), and Pierro v. Baxendale, 20 N.J. 17, 118 A.2d 401 (1955), shows a remarkable similarity.

50 It is too much to expect, or at least it is a dangerous experiment to suppose, that the profound and dependable patriotism which is necessary to preserve and maintain an ideal government like ours could survive the lapse of time crowded into apartments and tenements

City of Jackson v. McPherson, 162 Miss. 164, 176, 138 So. 604,605 (1932). This attitude was quite typical at the time; witness, for example, the comment of President Hoover's Secretary of Commerce, Robert P. Lamont: "It is doubtful whether democracy is possible where tenants overwhelmingly outnumber home owners." THE PRESIDENT'S CONFERENCE ON HONE BuIDING AND HOME OWNERSEIP; HOME OWNERSEIP, INCONE AND TYPES OF DweLLING vii (1932); see also text accompanying note 1 supra. 
The establishment of such districts is for the general welfare because it tends to promote and perpetuate the American home. . . The home and its intrinsic influences are the very foundation of good citizenship, and any factor contributing to the establishment of homes and the fostering of home life doubtless tends to the enhancement not only of community life but of the life of the nation as a whole. . . . With ownership comes stability, the welding together of family ties and better attention to the rearing of children. With ownership comes increased interest in the promotion of public agencies, such as church and school, which have for their purpose a desired development of the moral and mental make-up of the citizenry of the country. ${ }^{51}$

These early courts seemed to find a cause and effect relationship between numerous families per structure and the social problems of the occupants of poorer neighborhoods. This cause and effect relationship justified the exclusion of multiple-family housing from the "better neighborhoods," since the intrusion of multiple-family housing would produce all of the evils associated with the worst tenement neighborhoods.

Nevertheless, there were dissenting opinions; a few judges in the 1920 's believed that the restriction of multiple-family housing to segregated districts could not be constitutionally justified. The most perceptive analysis of the weak spots in early zoning regulations is in an opinion of Ohio Supreme Court Justice Florence E. Allen, who recognized the fallacy in the argument that the social problems existing in some tenement neighborhoods justified the segregation of all multiplefamily housing:

Does the apartment house per se endanger the public health, morals, or safety? It is true that noise affects health through nerve strain, and the apartment house is attacked upon the ground of noise; but the people who live in apartment houses may not of themselves be as noisy as people who live in private houses. . . . There is not per se more danger from fire from an apartment house than from a private house, for modern apartments are apt to be fireproof, as is contemplated in this instance. . . . Neither are the people who live in apartment houses less moral per se than those who live in single dwellings. ${ }^{52}$

51 Miller v. Board of Public Works, 195 Cal. 477, 492-93, 234 Pac. 381, 386-87 (1925). See also Minkus v. Pond, 326 III. 467, 158 N.E. 121 (1927).

52 City of Youngstown v. Kahn Bros. Bldg. Co., 112 Ohio St. 654, 662-63, 148 N.E. 842, 844-45 (1925); see Bjork v. Safford, 333 I1l. 355, 359, 164 N.E. 699, 701 (1928); Jersey Land Co. v. Scott, 100 N.J.L. 45, 126 Atl. 173 (Sup. Ct. 1924); Ignaciunas v. Risley, 98 N.J.L. 712, 121 Atl. 783 (Sup. Ct. 1923), aff'd sub rom. Ignaciunas v. Town of Nutley, 99 N.J.L. 389, 125 Atl. 121 (Ct. Err. \& App. 1924); Handy v. Village of South Orange, 118 Atl. 838 (N.J. 1922); cf. People ex rel. Friend v. City of Chicago, 261 I11. 16, 20, 103 N.E. 609, 611 (1913). 
To a few judges, the existence of separate districts for single-family and multiple-family housing constituted unconstitutional economic segregation, designed to impose by law separate neighborhoods for the rich and for the poor. ${ }^{53}$ This view was dominant for a time in the supreme courts of Minnesota ${ }^{54}$ and New Jersey. ${ }^{55}$ It was also expressed by a federal judge in Cleveland, who held invalid a zoning ordinance of the Village of Euclid, Ohio. "In the last analysis," said Judge Westenhaver, "the result to be accomplished is to classify the population and segregate them according to their income or situation in life." 56

This minority view, however, was soon overwhelmed. The Village of Euclid appealed to the Supreme Court, which, after a dramatic reargument, ${ }^{57}$ reversed the district judge and, in broad terms, upheld zoning. ${ }^{58}$ The most questionable practice said the Court, was the creation of "residential districts, from which business and trade of every sort, including hotels and apartment houses, are excluded." 58 However, it upheld the establishment of such districts, noting that "very often the apartment house is a mere parasite" ${ }^{60}$ which comes very near to being a nuisance. ${ }^{61}$

After the Euclid opinion, all the state courts fell in line, and the segregation of multiple-family dwellings became an accepted fact. "Promotion of the single-family home," wrote Alfred Bettman, "is deemed good public policy in America." ${ }^{2}$ The courts agreed.

This judicial attitude was perhaps understandable in the context of the early 1920's when the word "tenement" had an unpleasant social and economic connotation. However, the apparent carryover into the post-World War II era of this judicial antipathy toward the multiplefamily dwelling is less comprehensible. The anomaly of this current

53 The ordinance is nothing more nor less than a vast, comprehensive, and complete plan or scheme of segregation, under which the population of the city in respect to their dwelling places are graded and classified according to their means ....

Offutt, J., dissenting in R. B. Constr. Co. v. Jackson, 152 Md. 671, 690, 137 At1. 278, 286 (1927). See also Altschuler v. Scott, 5 N.J. Misc. 698, 137 Atl. 883 (Sup. Ct. 1927); Spann v. City of Dallas, 111 Tex. 350, 357, 235 S.W. 513,516 (1921).

54 See, e.g., State ex rel. Twin City Bldg. \& Inv. Co. v. Houghton, 144 Minn. 1, 174 N.W. 885 (1919), rev'd on rehearing, 176 N.W. 159 (1920). But see State ex rel. Beery v. Houghton, 164 Minn. 146, 204 N.W. 569 (1925), aff'd per curiam, 273 U.S. 671 (1927). 1924). 55 See, e.g., Jersey Land Co. v. Scott, 100 N.J.L. 45, 126 Atl. 173 (Sup. Ct.

56 Ambler Realty Co. v. Village of Euclid, 297 Fed. 307, 316 (N.D. Ohio 1924), rev'd, 272 U.S. 365 (1926).

57 See 1 Metzenbaum, Zoning 56-60 (2d ed., 1955).

58 Village of Euclid v. Ambler Realty Co., 272 U.S. 365 (1926).

$59 I d$. at 390 .

60 Id. at 394.

61 Id. at 395.

62 Bettman, Constitutionality of Zoning, 37 HARv. L. REv. 834, 839-40 (1924). 
judicial attitude can only be appreciated with the perspective that a study of the trend in residential building during the last three decades provides.

\section{Trends in Residential Building}

Although the Euclid case settled the validity of the segregation of multiple-family housing, the depression that followed almost made the question moot. New apartment buildings became so scarce that they constituted little threat to single-family neighborhoods. During the housing boom of the 1920's, a small apartment building was a typical investment for the elderly couple who today buys a motel. From 1924 through 1928 an average of 226,000 multiple-family dwelling units ${ }^{63}$ were constructed in the United States each year. ${ }^{64}$ It is difficult to obtain statistics on the geographic distribution of new multiple-family housing construction during that period, but the pattern of existing housing reported in the 1940 census indicates that the overwhelming preponderance of multiple-family housing was concentrated in the central cities. ${ }^{65}$ While some apartments were built in the inner ring suburbs during that period, ${ }^{66}$ multiple-family housing was concentrated by and large in solid blocks in the central cities. ${ }^{67}$

The small investor in the three-story flat did not fare too well in the 1930's, and his wealthier counterparts who owned elevator apartments did no better. ${ }^{68}$ The depression laid its hand on rich and poor alike, and to investors in apartment buildings the hand was heavy; foreclosures came at an alarming rate. ${ }^{69}$ The unamortized mortgage used in the 1920's ${ }^{70}$ left banks with collateral that was expensive to

63 Unless otherwise specified, the term multiple-family dwelling unit as used throughout this Article includes all dwelling units located in buildings containing two or more dwelling units. The term single-family dwelling unit includes only detached single-family dwelling units. We have not distinguished two-family dwellings from other multiple-family dwellings, although such a distinction is commonly found in zoning ordinances and is accepted by the courts. See Cosmopolitan Nat'l Bank v. Village of Mount Prospect, 22 Ill. 2d 463, 468-69, 177 N.E.2d 365, 368 (1961).

o4 HHFA, Housing Statistics, Annual Data 6 (April 1962); see Hoyt, ONe Hundred Years of I and Values in Chicago 238-40 (1933).

65 For example, of the $2,660,429$ dwelling units-other than single-family detached houses-located in the New York-Northeastern New Jersey Metropolitan District in 1940, 1,995,088 were located in New York City. U.S. BUREAU of THE CENSUS, Dep't of Commerce, Sixteenth Census of the United States: 1940, Housing, Characteristics by Type of Structure, Table F-1, at 246, Table L-1, at 252 (1945). ${ }^{66}$ The larger suburbs of the larger cities experienced extensive apartment development in the 1920's. The Presment's Conference on Hone BuIIDING aNd Home Ownerseip, Home Ownership, Incone and Types of Dwelling 198 (1932). ${ }^{67}$ See Woodbury, The Trend of Multi-Family Honsing in American Cities, $6 \mathrm{~J}$. of LAND AND PUBLIC UTIIITY ECoNomics 225 (1930).

68 Grebler, EXPERIENCE IN URban ReAL Estate Investanent 158 (1955).

69 There were 252,400 non-farm real estate foreclosures in 1933. HHFA, Housing Statistics, Annual Data 53 (April 1962).

70 Skilton, Governmental Policies in Land and Housing, 7 U. PITT. L. REv. 75, $79-80$ (1941); $c f$. Watson, Housing Problems and PossibIlitres in the UNITED States 63 (1935). See generally Winnick, Rental Housing: Opportunities for Private Investarent 73 (1958). 
maintain and impossible to sell. The resulting shock scared lenders out of the housing market. ${ }^{71}$

Only 21,600 apartment units were constructed in the United States in the average year from 1931 through $1935,{ }^{72}$ less than $10 \%$ of the rate during the late 1920's. While a large part of this decrease was due to a general decline in demand for housing, the market for multiplefamily housing suffered proportionately greater losses. ${ }^{73}$ Between 1924 and 1928, multiple-family housing starts averaged about $26.7 \%$ of all housing starts; ${ }^{74}$ during the early 1930's (1931-35), the proportionate rate of multiple-family housing starts was cut in half, amounting to only $13 \%$ of the total. ${ }^{75}$

Construction of multiple-family housing remained stagnant during the 1930's. Some defense-oriented multiple-family housing was constructed during the war years, but the postwar housing boom was concentrated in single-family dwellings, leaving the meager total of multiplefamily housing starts almost untouched. Between 1951 and 1955, the rate of multiple-family housing starts had dropped to $10.6 \%$ of all starts. $^{78}$ The story of the tract house and the VA loan, Levittown and backyard barbecues, picture windows and the morning kafe klatch is too familiar to need retelling.

With the approach of the 1960's, however, the trend began to reverse, and a new interest in multiple-family housing began to develop. From 1945 through 1957, single-family housing starts constituted between 84 and $91 \%$ of all housing starts ${ }^{77}$ in every year except one. ${ }^{78}$ By 1961, however, single-family starts had dropped to $74 \%$ of all housing starts; ${ }^{79}$ by 1962 , this percentage fell to $68 \% .^{80}$ The record 257,000 multiple-family housing starts in the year $1927^{81}$ went un-

71 Hoyt, One Hundred Years of Land Values in Chicago 272 (1933); see HaAr, Federal Credit and Private Housing 192-94 (1960).

72 HHFA, Housing Statistics, Annual Data 6-7 (April 1962). (1958).

73 WinNick, Rental Housing: Opportunities for Prdvate Investament 16

74 HHFA, Housing Statistics 5 (Jan. 1963).

75 Ibid.

76 Id. at 7.

77 HHFA, Housing Statistics, Historicax Supplement 11 (Oct. 1961). By contrast, $83.1 \%$ of the housing starts in Sweden in 1957 were multiple-family dwelling units. Hold, SwEDISH Housng (1959). The extensive reliance on high-rise apartments for new housing in Sweden has aroused many objections. N.Y. Times, Oct. 21, 1962, p. 34, col. 1 (city ed.). One Swedish magazine has dubbed them "people silos." See Varfor, Hemmet, Oct. 1962, p. 15.

${ }^{78}$ A brief flurry of apartment construction took place in the late 1940's as builders took advantage of the liberal provisions of section 608 of the Federal Housing Act. But the "Tịtle VI scandals" quickly brought an end to this construction. See Klaman, The Postwar Resmential Mortgage Market 113-14 (1961).

79 HHFA, Housing Statistics 5 (Jan. 1963).

80 HHFA, Housing Statistics 5 (March 1963).

81 HHFA, Housing Statistics, Annual Data 6 (April 1962). 
matched until 1961, when 338,400 multiple-family units were constructed. Even this figure was topped in 1962 , by a total of 461,800 units. 82

Unlike the housing boom of the 1920's, today's new multiplefamily housing activity is not concentrated solely in the central cities. The dramatic difference between the new housing boom and the old is the trend toward construction of apartment buildings in the suburbs. The extent of this trend varies widely from area to area. A sampling, however, will give a fairly clear picture of the extent to which multiplefamily housing has penetrated the suburban housing picture. The following table shows the ratio of multiple-family dwelling units to all dwelling units constructed during 1961 in the suburban sections of sample metropolitan areas. ${ }^{83}$

\begin{tabular}{|c|c|c|c|}
\hline $\begin{array}{c}\text { Standard Metropolitan } \\
\text { Statistical Area } \\
\text { (suburban sections only) }\end{array}$ & $\begin{array}{l}\text { No. of multiple- } \\
\text { family dwelling units }\end{array}$ & $\begin{array}{c}\text { No. of all } \\
\text { dwelling units }\end{array}$ & $\begin{array}{c}\text { Multiple-family } \\
\text { units as a } \\
\text { percentage of } \\
\text { all dwelling units }\end{array}$ \\
\hline Atlanta .............. & 1,058 & 8,620 & $12.3 \%$ \\
\hline Boston ............... & 3,871 & 10,756 & $36.0^{\circ}$ \\
\hline Chicago ............... & 8,919 & 29,914 & 29.8 \\
\hline Denver $\ldots \ldots \ldots \ldots \ldots \ldots$ & 5,274 & 14,897 & 35.4 \\
\hline Los Angeles ........... & 32,057 & 69,367 & 46.2 \\
\hline Miami $\ldots \ldots \ldots \ldots \ldots$ & 2,288 & 8,390 & 27.3 \\
\hline Philadelphia.$\ldots \ldots \ldots \ldots$ & 3,240 & 15,265 & 21.2 \\
\hline Portland (Ore) $\ldots . \ldots$. & 688 & 5,220 & 13.2 \\
\hline Washington, D.C. ...... & 11,260 & 23,707 & 47.5 \\
\hline
\end{tabular}

In many metropolitan areas, the contrast between new construction and existing suburban housing is sharp. The 1960 census reports that only $13.88 \%$ of the existing dwelling units in the Los Angeles suburban area were multiple-family housing. ${ }^{84}$ But as the above table shows, 46.2\% of Los Angeles suburban housing starts during 1961 were in multiple-family housing.

Nor is new apartment construction concentrated in only a few suburbs in each metropolitan area. During 1961, permits for multiplefamily housing were issued by 32 of the suburbs in the Cleveland area, ten of these suburbs issuing over 100 multiple-family permits each. ${ }^{85}$ On Long Island alone, six suburbs each issued over 200 multiple-

82 HHFA, Housing Statistrcs 5 (March 1963).

83 This table was computed from statistics in U.S. BuREaU of the Census, Dep'T of Commerce, Construction Reports, Buinding Permits Tables 1-2 (C40 ser., No. 38, July 1962).

84 See U.S. Bureau of the Census, Dep't of Comarerce, Census of Housing: 1960, Final Report HC(1)-6, State and Small Areas, California Table 14, at $6-40$ to -42 (1962).

85 U.S. Bureau of the Census, Dep't of Commerce, Construction Reports, BuILdING Permits 93 (C40 ser., No. 38, July 1962). 
family permits during $1961 .^{86}$ In the Los Angeles area, where 93 suburbs reported the issuance of some type of building permits in $1961,{ }^{87} 76$ of them issued permits for multiple-family housing. ${ }^{88}$

Where available, 1962 statistics show no major change. A local survey shows that the Chicago area suburbs issued 11,371 permits for multiple-family dwelling units in 1962 as compared to 8,720 in $1961 .^{89}$ The trend toward suburban apartments shows no sign of abating.

\section{The Economics of the Apartment Boom}

Is the boom in suburban multiple-family housing a result of a real demand on the part of the housing consumer, or is it the result of financial incentives which encourage the construction of multiplefamily housing?

In the present economic and legal climate, incentives are available not only to the landowner, but to the developer, the investor, and the lender. The basic process which creates incentives for the landowner to erect high-density housing has been discussed in detail in numerous articles dealing with the general problem of urban sprawl.90 Briefly, the price placed on open land in a suburban area is highly speculative, varying greatly with the expected density of development; the higher the permitted density, in general, the higher the land value. ${ }^{91}$ Since densities are usually higher in multiple-family dwellings than in singlefamily housing, it is generally to the landowners' financial interest to construct multiple-family housing.

86 Id. at 90 .

$87 \mathrm{Id}$. at 6.

88 Id. at 74.

89 See Bell Savings and Loan Ass'n, Survey of New Building, Chicago-Metropolitan Area, Jan. 15, 1963. In the midwestern region, multiple-family units accounted for $35 \%$ of all new units. Advance Mortgage Corp., Midwest Housing Markets, Fourth Quarter 1962, p. 2.

Housing starts for January, 1963, show a continuation of the trend.

Apartment units in the entire area totaled $883,4 \%$ above last year (851

units) and $9 \%$ above 1961 ( 812 units). Suburban apartments accounted for

the entire increase above last year with 430 units compared to 383 in 1962.

Bell Savings and Loan Ass'n, Survey of New Building, Chicago-Metropolitan Area, Feb. 15, 1963.

90 Whyte, Urban Sprawl, in The Exploding Metropolis 115 (Editors of Fortune 1958). For good local studies see Lower MaInLand Regronal Planning Board of British Columbia, Economic Aspects of Urban Sprawl (1956); Twin Cities Metropolitan Planning Commisson, Metropolitan Land Study (1960). See also Bollens, Urban Fringe Areas-A Persistent Problem, 42 Public Management 218 (1960) ; Clawson, Urban Sprazel and Speculation in Urban Land, 38 LAND EcoNOMICS 99 (1962).

91 "Land bought for $15 \phi$ a sq. ft. for houses can get a $75 \%$ a sq. ft. appraisal for apartments as a general rule." Murray, How to Make Money Building Apartment Houses-And How to Keep Most of the Money After Taxes, House \& Home, Oct. 1960, pp. 114f, 114g. 
Often a parcel of land which originally would have been economically feasible for single-family development is by-passed ${ }^{22}$ by developers and is traded at such a high, speculative price ${ }^{93}$ that singlefamily development would be uneconomic. ${ }^{94}$ The inner suburbs, belatedly concerned about "suburban blight," have enacted strict subdivision regulations which substantially increase the cost of development. ${ }^{95}$ Therefore, unless multiple-family housing is permitted, the latest owner must suffer a loss, since single-family developers will pass over the parcel and buy farther out in the suburbs. ${ }^{96}$ In addition, taxes have risen with land values. This combination of incentives often makes a landowner willing to risk the sizable expense involved in an attempt to obtain a rezoning of the property for multiple-family housing.

The builder also has incentives to construct multiple-family housing. The construction and sale of single-family housing, which has been such a successful business for the last fifteen years, is becoming much more difficult. Construction costs have risen at twice the rate of the general price level; ${ }^{97}$ suburban land prices have risen even faster. ${ }^{98}$ With every increase in the real dollar cost of single-family housing, more and more people are priced out of that market and into the market for multiple-family housing. With the end of the postwar housing shortage, the customer is no longer willing to live in any old shack he can find. The large number of available single-family dwellings ${ }^{30}$ provides an alternative.

The investor is also encouraged to invest in multiple-family housing. ${ }^{100}$ The Internal Revenue Code of 1954 permits the use of accel-

92 "In nearly every market, realtors and builders and developers either own or know of by-pass lots that can be converted into high-paying investments with small apartments." Simall Apartments, House \& Home, July 1961, p. 166.

${ }^{93}$ See Berkman, Decentralization and Blighted Vacant Land, 32 LAND EcoNonrcs 270 (1956).

94 Historically, expensive land has meant more apartment construction. WINNICK, op. cit. supra note 73, at 223; see VerNoN, METropolis 1985, at 140 (1960).

95 See Ledermann, Homebuilding and the Urban Growth Process, J. of the American Institute of Architects, Sept. 1961, p. 33; BANFIELd \& GrodzINS, Government and Housing in Metropolttan AREas 78-82 (1958); Meyerson, Terrett \& Wheaton, Housing, People and Cities 2 (1962). (1962).

96 See Vernon, The Myth and the Reality of Our Urban Problems 15-17

97 Foote, Abu-Lughod, Foley \& Winnick, Housing Choices and Housing Constraints 13-16 (1960).

98 Single-family developers in some sections are resorting to the old Maryland ground rent system of selling a house but giving the buyer only a long-term lease on the underlying land. See Wall Street Journal, Feb. 25, 1963, p. 1, col. 4.

99 See HHFA, Housing Statistics 10 (Feb. 1963).

100 Foreign investment in United States real estate has increased sharply in recent years. See Wall Street Journal, Nov. 15, 1962, p. 1, col. 6. 
erated depreciation ${ }^{101}$ to promote new capital investment. The ability to charge off high percentages of the original cost of a new building during the early years of the building's life increases the net anticipated cash flow from the building during those years, thereby fostering the construction of new buildings. However, accelerated depreciation is made available not only for newly created buildings, but also for "second-hand" buildings. In effect, the Code allows a permanent "double depreciation" to be taken on buildings which are traded every few years. In addition, the difference between the sale price and the seller's cost less accelerated depreciation is taxed only at the lower capital gains rate. ${ }^{102}$

Accelerated depreciation has spawned the great game of "hot potato" that has so intrigued real estate investors in the last few years. The "potato" is a piece of income-producing real estate, often an apartment building. The investor purchases the property, balances gross income with accelerated depreciation, and then draws all the gross income down as a tax-free return of capital. ${ }^{103}$ When his rate of depreciation decelerates to a point where income is no longer tax-free, the original investor sells or trades the "potato" to another investor who, instead of taking over the prior owner's depreciation schedule, begins the process all over again by taking accelerated depreciation on his own purchase price. ${ }^{104}$

This process has encouraged the planting of many new "potatoes" in the form of multiple-family housing. Only time will determine the soundness of many of these investments. Syndicates ${ }^{105}$ have been formed to bring the benefits of the process to the small investor. ${ }^{106}$ Most of these projects are sponsored by reliable real estate specialists, and are economically sound. But the demand to be let into the game

101 Int. Rev. CODE of 1954, \$167(b); cf. Blum \& Bursler, Tax Subsidies for Rental Housing, 15 U. CHI. L. REv. 255, 261-64 (1948).

102 The Kennedy administration's proposal to tax the gain that results from accelerated depreciation at ordinary income rates has encountered strong opposition from the building industry. See Wall Street Journal, Jan. 30, 1963, p. 1, col. 6.

103 Whether the draw-down constitutes real income or a return of capital depends on the market value of the building at any given time. In a rising real estate market, there is often no real depreciation in the value of the building so the draw-down constitutes a real gain. In a declining market, the decline in value of the building over a year may equal or exceed the draw-down. The draw-down would then in fact constitute a return of capital.

104 See Winnick, op. cit. supra note 73, at 145 . Regarding the effect of these tax loopholes on the operation of slum housing, see Sporn, Some Contributions of the Income Tax Law to the Growth and Prevalence of Slums, 59 Colum. L. Rev. 1026 (1959).

105 See generally Berger, Real Estate Syndication: Property, Promotion, and the Need for Protection, 69 Y ALE L.J. 725 (1960).

106 Land syndication, while formerly restricted primarily to downtown areas, is becoming common in suburbia. See Singleton \& Scofield, Land Syndication and the Rural-urban Fringe, 30 ApPRAISAI J. 494 (1962). 
has been so great, and the sale of shares in syndications so easy, that many marginal apartment projects of doubtful long-term economic potential have been constructed, and vacancies have already become a serious problem for many syndicates. ${ }^{107}$

The high risk potential of many small real estate syndicates may be alleviated by the increased use of larger, more diversified real estate corporations ${ }^{108}$ and investment trusts, ${ }^{109}$ but even the larger corporations have been having their difficulties. ${ }^{110}$ However, the large syndicates that have attempted to sell shares on the open market have concentrated their holdings primarily in big luxury apartment projects in the central cities, especially New York. The suburban projects are typically instituted by smaller groups of investors who will be unaffected even if some of the publicly-held syndicates collapse.

Although the effect is more indirect, federal policies relating to lending institutions have also encouraged the construction of multiplefamily housing in the suburbs. The statutes controlling FHA and VA policy still favor single-family housing in suburban areas; ${ }^{111}$ only in the urban renewal arena have liberalized terms for multiple-family housing been available. But FHA policy does not play a controlling role in the field of suburban multiple-family housing. The numerous small savings and loan associations ( $\&$ l's) which have never been afraid to invest in conventional uninsured loans, ${ }^{112}$ are the major source of debt capital for the suburbs.

The small s \& l's are concerned with the over concentration of single-family dwelling mortgages in their portfolios. ${ }^{113}$ This concentration looks especially risky today in light of the large number of

107 Wall Street Journal, July 25, 1962, p. 1, col. 1.

108 Wall Street Journal, Jan. 22, 1963, p. 1, col. 1.

109 See generally N.Y.U. 20th INST. on Fed. TAX 609-98 (1962).

110 See generally The Developing Scandal in Syndication, House \& Home, Feb. 1963, p. 42; O'Donnell, Real Estate Woes: Unorthodox Financing Brings Many Syndicates to Grief, Wall Street Journal, March 11, 1963, p. 14, cols. 4-5.

"Apartment development has remained a stronghold of highly individualistic and aggressive entrepreneurs, not all of whom regard themselves as candidates for canonization." WINNICK, op. cit. supra note 73, at 183.

111 See generally WINNICK, op. cit. supra note 73, at 241; HAAR, FEDERAL CREDIT and Private Housing 194-96 (1960); Megyerson, Terrett \& Wheaton, Housing, PEOPLE, AND CiTIES 13 (1962).

112 In 1961, federally insured $s \& 1$ 's held $\$ 54,684,000$ in conventional mortgages and only $\$ 10,841,000$ in FHA-insured or VA-guaranteed mortgages. FEDERAI HOME Loan Bant Board, Savings and HoMse Financing Source Book 22 (1962); see Morton, Urban Mortgage Lending Comparative Markets and Expertence 52-54 (1956); National Association of Real Estate Boards, The Mortgage Market, Autumn, 1962 , at 16.

113 In 1956 only $2.7 \%$ of the aggregate s \& 1 portfolio was in five-family or more multiple-family housing mortgages. KLAMSAN, THE POST-WAR RESDENTIAL HousING Market 37 (1961). 
foreclosures of mortgages on single-family houses ${ }^{114}$ and the commonly heard predictions of a decrease in potential housing purchasers. ${ }^{115}$ In an attempt to seek diversification in their portfolios, ${ }^{116}$ the $s \&$ l's are encouraging the construction of multiple-family housing. ${ }^{117}$ They have, for example, recently obtained the easing of the federal restrictions which limit the extent of their investment in multiple-family housing. ${ }^{118}$ The typical $\mathrm{s} \& 1$ is not large enough to participate in the big multiple-family housing projects in the central city, nor does it feel comfortable outside the local neighborhood in which it grew up. Suburban apartments are, therefore, the common and easy answer to the $s$ \& l's need for diversification. ${ }^{119}$

The increased interest of $s$ \& l's in multiple-family housing loans has come at a time when other market pressures have forced the traditional holders of apartment mortgages-insurance companies ${ }^{120}$ and the large saving banks ${ }^{121}$ - to compete vigorously for mortgages. ${ }^{122}$

114 There were 18,141 non-farm real estate foreclosures in 1951. HHFA, Housing Statistics, Historical Supplement 152 (Oct. 1961). There were 73,074 in 1961 , and 64,399 in the first nine months of 1962. HHFA, Housing STATIstrcs 23 (Feb. 1963).

115 E.g., Silberman \& May, The Coming Changes in Housing, in MARKETS of THE SIXTIEs 146-47 (Editors of Fortune 1960). The marketability of much postwar single-family housing is unfavorably affected by its small size. Four-room dwelling units were the size most frequently constructed in 1950. WINNICK, AMERICAN HousING AND ITS USE 75 (1957).

116 See 108 Cong. REC. 18505-07 (daily ed. Sept. 17, 1962).

117 See, e.g., Denver Planning Office, Apartament Growth in Denver 7, 31 (Bulletin No. Z-14, Oct. 1961).

11876 Stat. 778, 12 U.S.C.A. \$1464 (Supp. 1962); 76 Stat. 779, 12 U.S.C.A. $\$ 1422$ (Supp. 1962).

119 Activity in loans for miscellaneous uses (such as modernization, recon-

ditioning and refinancing of homes, land development, and apartment financ-

ing) increased in volume 23 percent over 1961, and together accounted for

30 percent of all lending in 1962.

Federal Home Loan Bank Board, FSLIC Insured Savings and Loan Associations, Savings and Mortgage Iending Activity-Selected Balance Sheet Items 3 (Dec. 1962). The pressure for increased freedom to make apartment loans comes from the savings and loan associations located in the major metropolitan areas. See Hearings on H.R. 13044 Before a Subcommittee of the Senate Committee on Banking and Currency, 87th Cong., $2 \mathrm{~d}$ Sess. 21 (1962). It is primarily these areas that are witnessing the new boom in apartments.

Because so many suburban apartments are being financed through $s$ \& 1's without government insurance, it is unlikely that the President's housing anti-discrimination order will have any substantial effect either on the volume of apartments being constructed or the racial characteristics of their occupants. The order at this time does not affect financing of this type. See Exec. Order No. 11063, 27 Fed. Reg. 11527 (1962).

120 The 1950's saw a trend away from large life insurance housing projects. See Winnick, Rental Housing: Opportunities for PrTvate Investment 15, 121-30 (1958).

121 See Klaman, The Postwar Resmential Mortgage Market 36-37, 155 (1961); Morton, UrbaN Mortgage Lending: CoMparative Markets aND EXPERIENCE 43-54 (1956); Federal Reserve Bank of Chicago, Business Conditions, Oct. 1962, p. 16.

122 See National Association of Real Estate Boards, The Mortgage Market, Autumn, 1962, at 7 (1962). 
Interest rates on corporate bonds have declined while mortgage interest rates have remained high. ${ }^{123}$ Each insurance company must therefore hold a percentage of mortgages not much lower than the percentage held by competing companies or risk falling behind in its investment income rate. In addition, increases in interest rates paid by commercial banks on savings deposits have brought a resurgence of interest in mortgages on the part of the commercial banks, an interest that had been substantially absent for thirty years. ${ }^{124}$ As a result of all of these market pressures, the early 1960's have become more of a borrower's market in mortgages, ${ }^{125}$ a condition which has stimulated multiplefamily housing construction. ${ }^{126}$

Regardless of the number of incentives created by the government and the housing market, the amount of multiple-family housing that will be constructed is limited by the demand. Developers, investors, and lenders will not sponsor multiple-family housing projects unless they anticipate that occupants will be available to fill them. The housing industry, however, believes that the demand is there. The industry's analysis rests primarily on three simple propositions:

(1) People age 30 to 40 buy houses, while people age 20 to 30 rent apartments. The birth rate in the 1930's was low; in the 1940's it was high. During the 1960's, therefore, there will be many potential tenants but few potential buyers. ${ }^{127}$

(2) Increased longevity has greatly enlarged the number of older people. Social trends encourage these people to occupy separate dwelling units rather than to double up with their children. ${ }^{128}$ It is

123 Fluctuations in mortgage interest rates are minimal compared to most other types of securities. See KLAMAN, op. cit. supra note 121, at 77-78.

124 Wall Street Journal, Dec. 13, 1962, p. 1, col. 1; see MoRTon, op. cit. supra note 121. Pension funds, which are now invested predominantly in equity securities, are also a large untapped source of mortgage capital. See KIAMAN, op. cit. supra note 121, at 173-74. Should pension trustees become disillusioned with common stocks, it would increase the pressure on the mortgage market.

125 See, e.g., Addresses by Joseph P. McMurray, Chairman, Federal Home Loan Bank Board, A Year Ahead, Nov. 5, 1962; Money and Mortgages, Nov. 13, 1962.

126 The FNMA has recently raised the price of the FHA and VA mortgages it holds for resale in an attempt to keep mortgage money flowing into new construction rather than into existing mortgages. Wall Street Journal, Feb. 11, 1963, p. 6, cols. 3-4 (Midwest ed.).

127 Silberman \& May, supra note 115, at 140-42; Foote, ABU-Lughod, Foley \& WINNICK, op. cit. supra note 97 , at 108 ; KeLLY, DESIGN AND THE Production of Houses 377 (1959); Vernon, MEtropolis 1985, at 159 (1960); Christie, All About Apartments, Building Business, Jan. 1963, p. 2; Colean, 1963 Homebuilding Forecast, House \& Home, Nov. 1962, p. 82; Fergusson \& Valenti, Houtsing in a Growth Economy, 38 Land Economics 9, 14-16 (1962) ; U.S. Dep't of Commerce, The Construction Outlook for 1963, Constr. Rev., Nov. 1962, p. 4.

128 See Beyer, Economic Aspects of HousIng For the Aged 38 (1961) ; WINNICK, AMIERICAN Housing AND ITS USE 82-88 (1957); Smith, The Housing Preferences of Elderly People, $16 \mathrm{~J}$. of GERONTOLOGY 261, 265 (1961). There has also been an increased tendency on the part of young married couples to form their own household immediately. WINNICK, op. cit. supra at 100. 
usually more convenient for older people to rent than to buy. ${ }^{129}$ Thus there will be an increased demand for multiple-family housing for them. ${ }^{130}$

(3) Many industries are moving to suburban areas. ${ }^{131}$ Their employees want to live near their places of employment, but cannot afford expensive housing. ${ }^{132}$ Therefore, they will look for suburban multiple-family housing.

The types of multiple-family dwellings now being constructed have changed considerably from the relatively standardized housing styles which formed the existing conditions on which these propositions are based. ${ }^{133}$ The question arises whether this will weaken the predictive value of propositions based on past events. ${ }^{134}$ More bluntly, will the demand for the new types of suburban ${ }^{\mathbf{1 3 5}}$ multiple-family housing, such as the low-density row house, the suburban high rise, and the condominium, be significantly different from the demand for earlier styles of multiple-family housing? Although the answer involves a large measure of speculation, it seems that the demand for multiplefamily housing should be broadened by the increased variety in types of multiple-family housing now being constructed. ${ }^{136}$ More and more multiple-family housing is being constructed which performs functions

129 Foote, ABU-Lughon, Foley \& Winnick, op. cit. supra note 115, at 50; HHFA, Senior Citizens and How They Live 10 (1962).

130 E.g., Christie, supra note 127 , at 3. Many existing suburbanites who return to apartments will probably stay in the suburbs rather than return to the central city. VernoN, METROPOLIS 1985, at 159 (1960). The builders of the more expensive suburban apartments are expecting to attract the existing suburbanite who no longer wishes to maintain a large house but wants to remain close to his suburban friends. See, e.g., Winnetka (I11.) Talk, April 26, 1962, p. 43, cols. 1-3; Chicago Daily News, Nov. 22, 1961, §2, p. 13, cols. 7-8.

131 See, e.g., Fergusson \& Valenti, Housing in a Grozeth Economy, 38 LAND Economics 9, 16 (1962) ; Vernon, The MYth and Reality of OUR Urban ProbLeMs 19, 24 (1962); GotTMan, MEgalopolis 210 (1961).

132 But see a recent study which indicates that industries employing low-wage workers tend to relocate in the South, while the industries which relocate in the North pay relatively higher wages. Fuchs, Changes IN THE Location of MaNuFACTURING IN THE UNITED STATES SinCe 1929, at 124-25 (1962).

133 For a sample see Today's Good New Apartments: What Makes Them Good, House \& Home, Oct. 1960, p. 100.

134 See Duncan \& Hauser, Housing a Metropolis-Chicago 242-43 (1960). For an analysis which fails to give sufficient weight to changing conditions in the building industry see FOOTE, ABU-LUGHOD, FOLEY \& WINNICR, op. cit. supra note 97, at $179-214$.

135 On the competition between central city multiple-family housing and suburban multiple-family housing see Frieden, Locational Preferences in the Urban Housing Market, 27 J. OF THE AM. INST. OF PlanNers 316 (1961).

136 See, e.g., Strauss, Images of the American City 243-44 (1961); Foote, ABU-LUGEOD, FOLEY \& WINNICK, op. cit. supra note 97, at 141-43, 259-60. Louis Winnick estimates that one out of five homebuyers would have preferred to rent. Winnick, Rental Housing: Opportunities for Private Investanent 5 (1958); cf. Eldredge, Housing Preferences in the USA, 30 Town aND Country Planning 369 (1961). See also Rosst, Why FaxmIEs Move 156 (1955). 
previously associated only with single-family housing. ${ }^{137}$ The lowdensity suburban row house affords easy child care, fresh air, and quiet formerly obtainable only in a single-family house. ${ }^{138}$ The suburban high rise cooperative affords luxury living in the suburbs which was never previously available in multiple-family housing. ${ }^{139}$ Conversely, the only conceivable technical improvement ${ }^{140}$ in singlefamily housing, says economist Louis Winnick, is the long-term low down-payment mortgage. ${ }^{141}$ We may speculate, then, that to the extent that consumers do make rational selections in choosing housing types, the predictions based on past trends are conservative; the 1960's will witness a demand for multiple-family housing even greater than is now being predicted. ${ }^{142}$

\section{The Suburban Reaction to Multiple-Family Dwellings}

Despite the increased consumer demand for suburban apartments and the apparent surge of new apartment construction, suburbia has not embraced the multiple-family dwelling with open arms. On the contrary, the battle lines are drawn, with the builder and investor (representing, if you will, nameless thousands of potential suburban apartment dwellers) on one side, and the residents of suburban singlefamily houses on the other. In the middle are the local suburban legislative bodies and planning commissions. Since the residents vote

137 The HHFA recently approved a grant for experimental apartment houses utilizing new building techniques. See 28 ASPO NewSLETTER 92 (1962).

138 American Soc'y of Planning Offictals, Row Houses (Planning Advisory Serv. Information Rep. No. 164, Nov. 1962); Garden Apartments and Toumhouses, House \& Home, Feb. 1963, p. 85; WILson \& Christie, Group House Study For THE Planning Board, Baltimore County, Mo. (1961); Foote, Abu-Lughod, Foley \& WinNICK, op. cit. supra note 97, at 202 . See generally Galiton, The URBan PATtern: City PlanNing and Design 123-25 (1950).

139 See, e.g., Urban Land Institute, New Approaches to Residential Land Development (Technical Bull. No. 40, Jan. 1961).

140 This does not reflect a weakness of technology as much as a weakness in the "rules" of the construction industry which have hampered the use of prefabrication. Loevinger, Handicraft and Handcuff-The Anatomy of an Industry, 12 LAW \& Contens. Prob. 47 (1947); see Burchard \& Bush-Brown, The Architecture of AMIERICA 227 (1961). Although prefabricated housing has greatly increased its share of the market for single-family housing, substantial social and political changes will be required if the "pre-fab" is to reclaim the share of the housing market which has been lost to the apartment building. But see TeBbed, THE SLUM MARERS 52-55 (1963). Builders in European countries and some American builders are experimenting with prefabricated apartments. See Holm, SwEDrsn HousING 85-93 (1959); Barrons, May 21, 1962, pp. 1-2. The increasing popularity of mobile homes shows the extent to which the market for fixed single-family housing could be increased if technology were permitted free rein. See Constr. Rev., Oct. 1962, p. 22. (1958).

141 Winnick, Rental Housing: Opportunities for Private Investament 3

142 The vicissitudes of the housing business being what they are, the authors must acknowledge the possibility that the bottom might drop out of the apartment market shortly after this Article goes to press. Our only wish, should this occur, is that the ideas expressed herein will be read for their broad, long-range significance. After all, what goes down must come up. 
and the builders do not, the latter commonly lose the first round. If they are persistent, the next battleground is the court. ${ }^{143}$

The suburban attitude is reflected in numerous ways. A few suburbs have attempted to prohibit all multiple-family housing within their corporate limits. ${ }^{144}$ Other suburbs continue the archaic practice of relegating multiple-family housing to the second floors of buildings in commercial zones. ${ }^{145}$ More imaginative communities have limited apartment use to the area already occupied by apartments, thus segregating all other areas without being subject to the charge of total exclusion. ${ }^{146}$ An even more sophisticated gambit, designed to give the community a look-see at each specific proposal for multiple-family development, is to treat the apartment as a "floating zone," with a provision for such a district in the text of the local zoning ordinance, but with no corresponding district on the map. ${ }^{147}$

The less daring and by far the most common treatment of multiplefamily housing is to provide apartment zones in areas which are not considered desirable for single-family residences. ${ }^{148}$ Usually this re-

143 Neighbors may often hold up construction of an apartment for years. Wynnewood Civic Ass'n v. Board of Adjustment, 406 Pa. 413, 179 A.2d 649 (1962). But at times the neighbors end up paying. See Weiner v. 222 E. Chestnut St. Corp., 303 F.2d 630 (7th Cir.), cert. denied, 371 U.S. 935 (1962).

144 Some courts have upheld such ordinances, although not in cases involving apartment uses. E.g., Valley View Village v. Proffett, 221 F.2d 412 (6th Cir. 1955); Connor v. Town of Chanhassen, 249 Minn. 205, 81 N.W.2d 789 (1957). In other jurisdictions they have been struck down. E.g., Town of Hobard v. Collier, 3 Wis. 2d 182, 87 N.W.2d 868 (1958); City of Sherman v. Simms, 143 Tex. 115, 183 S.W.2d 415 (1944).

145 The zoning ordinance of Lake Forest, Ill. permits apartments over stores in the commercial district. Apartments are not permitted elsewhere in the city. A builder recently sought to have the ordinance amended to allow him to erect apartments in the commercial zone without devoting the first floor to commercial use. In response to pressure from "enlightened" civic organizations such as the League of Women Voters, the City refused to amend the ordinance. The builder proceeded to construct his apartment building, leaving room for stores on the first floor. See The Lake Forester Sept. 20, 1962, p. 1, col. 5. This practice was disapproved even in the early days of zoning. See BASSETT, ZoNING 85-86 (1936).

146 See, e.g., Fox Meadow Estates, Inc. v. Culley, 233 App. Div. 250, 252 N.Y. Supp. 178 (1931), aff'd per curiam, 261 N.Y. 506, 185 N.E. 714 (1933); cf. June v. City of Lincoln Park, 361 Mich. 95, 104 N.W.2d 792 (1960).

147 See, e.g., Rodgers v. Village of Tarrytown, 302 N.Y. 115, 96 N.E.2d 731

(1951). But see Eves v. Zoning Bd. of Adjustment, 401 Pa. 211, 164 A.2d 7 (1960).

148 While a municipality may not expressly prohibit the erection of apartment buildings or restrict permissible locations to districts unfit for human habitation or already overcrowded with buildings of a permanent nature, the record indicates that such is not the effect of the ordinance challenged here. By its provisions, apartment buildings may be built in commercial or industrial districts.

Speroni v. Board of Appeals, 368 Ill. 568, 572, 15 N.E.2d 302, 304 (1938).

A discussion then ensued on the subject of row houses, apartments and "garden apartments." It was the consensus of opinion of the members present that properly controlled "garden apartments" in areas not particularly suitable for single-family dwelling units construction because of proximity to railroad tracks, etc., appeared to be desirable and necessary.

Proceedings of the Plan Comm'n of City of Lake Forest, May 31, 1949. 
sults in placing multiple-family dwellings adjacent to commercial districts. This is justified, or at least believed to be adequately explained, by the overused word "buffer." 149 Multiple-family housing districts are inserted between single-family and commercial districts on the odd assumption that although it is bad planning to abut singlefamily houses against business properties, it is good planning to place five families next to the same commercial sites. ${ }^{150}$ If this explanation is challenged, the customary riposte is that people who live in multiplefamily dwellings need to be next to commercial uses because they do not have the same vehicular conveniences as do their cousins in single-family homes. ${ }^{151}$ Besides, to many people, it is natural that apartments and stores should snuggle next to each other, since they are just two varieties of income-producing property. "The traffic noise and litter complained of already exist in large measure, and an apartment building is more compatible with such conditions than single-family residences." 152 In Maryland, a buffing stronghold, the courts have gone even further, justifying the existence of a multiplefamily buffer zone by the proximity of an incinerator, a highway maintenance garage, a county liquor warehouse, a shooting range, and the county dog pound. ${ }^{153}$

It is difficult to comprehend the depth of popular feeling in suburbia about the introduction of multiple-family dwellings unless one has had the dubious opportunity of participating in local hearings involving such proposals. It is probably fair to say that the emotional color of such a local debate is of a far darker hue than arguments about the introduction of commercial uses into partially developed

$140 \mathrm{By}$ means of this device [apartment zone], a so-called buffer area has been established to prevent an impact between the intensity of the use to which commercial areas are put with the quiet and cleanliness which are essential to property devoted to higher type residential uses.

Evanston Best \& Co. v. Goodman, 369 Ill. 207, 209-10, 16 N.E.2d 131, 132 (1938). "Buffing" is not a new technique. See Comey, Transition Zoning 29 (1933). But see BASSETT, ZONING 50-51 (1936).

Some real estate men even recommend the creation of buffers between singlefamily and multiple-family dwellings. "Buffers are generally to be considered desirable between multi-family units and single-family homes. It could be a small park, school or church; and well-designed double housing can be made to do the same job." United States Sayings and Loan League, What the Savings and Loan Associations Need To Know About Land Planning 27 (1956).

150 See Williams, Plaming Law and the Supreme Court, 13 Zonrng Digest 97, 105 (1961).

151 A recent survey, however, has shown that at least one automobile is owned by over eighty percent of the apartment households living in the suburbs over five miles from the center of Toronto. Metropolitan Toronto Planning Board, ApartMENT SURVEX, 1961, 100 (1962).

152 LaSalle Nat'l Bank v. Village of Skokie, 26 Ill. 2d 143, 147, 186 N.E.2d 46, 49 (1962) ; cf. Weglarz v. Village of Villa Park, 21 Ill. 2d 202, 171 N.E.2d 609 (1961); LaSalle Nat' Bank v. City of Park Ridge, 23 IIl. 2d 239, 177 N.E.2d 837 (1961).

153 Muhly v. County Council, 218 Md. 543, 545-46, 147 A.2d 735, 736 (1959); cf. Mayor of Rockville v. Cotler, 187 A.2d 94 (Md. 1963) (county dump): 
residential areas. It is this type of donnybrook, not merely permitted but required by law, ${ }^{154}$ which makes a rational analysis of zoning practice far more difficult than of other areas of the law in which the layman does not consider himself an expert.

Why does the suburbanite resist the introduction of multiplefamily housing? An analysis of his motives, both announced and unstated, is a prerequisite not only to a reappraisal of the judicial attitude toward the multiple-family dwelling but also to a meaningful evaluation of the chances of effecting change through legislation. The suburbanites' arguments can be broken down for analysis into three categories. At this point we will not discuss the propriety or legal validity of these contentions; we will merely examine their internal consistency.

\section{A. The Shouted Reasons}

The first category of arguments we will call the "shouted reasons." These are the reasons that one hears at the public hearings, and reads in the letters to the local editors and in advertisements, leaflets, and brochures. Many of these shouted reasons relate to questions of municipal finance. ${ }^{155}$

1. "Apartments don't pay their own way! If we allow apartments to come in, our taxes will go up!" ${ }^{156}$ A truly comprehensive analysis of the effect of various types of housing on local costs and revenues has yet to be prepared. ${ }^{157}$ However, from the limited number of local studies of this problem which are available, ${ }^{158}$ it is clear that multiple-family housing per se does not have any particular effect on municipal finance.

School costs are the largest single item of local expenditure. Local school officials usually believe that the effect of housing on

154 State statutes typically require a public hearing prior to any change in zoning. See, e.g., IlL. AnN. Star. ch. 24, §11-13-14 (Smith-Hurd 1962).

155 State courts differ in their willingness to accept problems of municipal finance as legally valid bases for zoning. Smith, Munticipal Economy and Land Use Restrictions, 20 LAW \& Contemp. ProB. 481 (1955). Compare LaSalle Nat'l Bank v. Village of Skokie, 26 Ill. 2d 143, 186 N.E.2d 46 (1962), and Hendlin v. Fairmount Constr. Co., 8 N.J. Super. 310, 328-30, 72 A.2d 541, 550-51 (Ch. 1950), and Bilbar Constr. Co. v. Board of Adjustment, 393 Pa. 62, 89, 141 A.2d 851, 865 (1958) (dissenting opinion), and Elkins Park Improvement Ass'n Zoning Case, $361 \mathrm{~Pa}$. 322, 64 A.2d 783 (1949), with Gruber v. Mayor of Township of Raritan, 186 A.2d 489, 493-94 (N.J. 1962), and Josephs v. Town Bd., 24 Misc. 2d 366, 198 N.Y.S.2d 695 (Sup. Ct. 1960).

156 See, e.g., Higbee, The Squeeze 134 (1960).

157 There is considerable controversy over cost-benefit analyses. See Wheaton, Applications of Cost-Revenue Studies to Fringe Areas, 25 J. OF THE AM. INST. of PlaANNers 170 (1959).

158 For a summary of numerous local studies and the best overall treatment of the problem see MACE, MUNicipal Cost-Revenue Research in tHe UNITEd STAtes 71-123 (1961) 
local school costs varies directly with the number of school children who will live in the housing as compared with its taxable valuation, ${ }^{159}$ regardless of whether multiple-family or single-family housing is involved. Thus, high density housing of cheap construction with numerous bedrooms per unit will increase school costs. School officials who depend on local tax support should, therefore, welcome an expensive high rise project which will attract few children, ${ }^{160}$ but oppose cheap housing for large families, whether single-family or multiple-family. ${ }^{161}$ However, not all educators have adequately analyzed the cost-revenue problem. They are often opposed to projects that would actually be very beneficial to the school district's tax base. One developer, seeking a rezoning in a Chicago suburb, offered, in vain, to "sign a covenant that his buildings would not contain three or more bedroom apartment units." 162

When not only schools but other types of municipal services are taken into consideration, the relationship between cost and revenue becomes far more complex, and a new variable enters. The developer is rarely required to build a school, ${ }^{103}$ but he often is forced to provide streets, sewers, waterworks, gutters, and many other municipal

159 See, e.g., Board of Education, School District 68, Skokte, Illinots, A

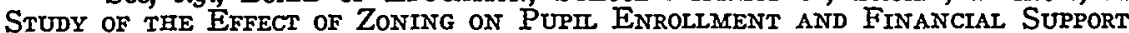
OF AN ELEMENTARY SCHOOL (1961). Such a formula assumes that the entire benefit of a child's education can be credited to his own family. However, it is a basic premise of our system of public education that the education of any one child is of benefit to our entire society. The requirement that each school child pay his own way is a return to regressive taxation. See Williams, Planning Law and Democratic Living, 20 LAW \& CoNTEMrP. Prob. 317, 345 (1955).

Nevertheless, in states where most of the cost of education is paid by property taxes collected in the local district, the burden on a local school district is truly measured by the ratio of school children to assessed valuation. The corrective needed may be increased state aid for schools. See Natronal Association of Home BUIIDERS, Schools AND URBAN GRowtH 5-6 (1962).

160 Melamed, High-Rent Apartments in the Suburbs, Urban Land, Oct. 1961, pp. 1, 4-6. Many garden apartment developments also meet this test. Weiss, Garden Apartments Are Good, The American City, Nov. 1961, p. 99; see Denver PlanNING Office, Apartarent Growth IN Denver, 21-22 (Bull. No. Z-14, Oct. 1961).

101 One local study of such housing comes to the additional conclusion that "lower priced houses produce more children than higher priced houses." Caruso, Effect of Mass Housing Development on School District No. 110, in Caruso, StmPHeN, Mrtchell \& Walchli, A Study of Selected Land Uses in DeerField, IlinNois, and Their Conconsmant Financial Implications (1962). But another local study, by planner George Raymond in Westchester County, N.Y., shows that larger, more expensive houses produce more children and more drain on the tax base than do smaller houses. House \& Home, June 1959, p. 65. See also Coke \& Liebman, Political Values and Population Density Control, 37 LAND Economrcs 347, 351 (1961).

162 Des Plaines (I11.) Suburban Times, Nov. 29, 1962, p. 15, col. 3.

163 The courts have frowned on municipal attempts to apportion an additional share of school costs to new residents. See Kelber v. City of Upland, 155 Cal. App. 2d 631, 318 P.2d 561 (Dist. Ct. App. 1957); Rosen v. Village of Downers Grove, 19 I11. 2d 448, 167 N.E.2d 230 (1960); Daniels v. Borough of Point Pleasant, 23 N.J. 357, 129 A.2d 265 (1957). 
services. ${ }^{104}$ Special assessment procedures are also used in order to pass on the cost of these services to the future occupants. ${ }^{105}$ When the incoming occupants pay for such services, the existing suburbanites' taxes are rarely raised. Even ignoring the problem of who pays, if the construction of streets, sewers, and water mains is necessary at all, then the higher the density of the housing, the cheaper the cost of installation and maintenance of these facilities will be per person, and, usually, per dollar taxable valuation. ${ }^{166} \mathrm{~A}$ high density multiplefamily housing project, therefore, would often seem to be the most economical type of housing that could be constructed insofar as the effect on municipal facilities is concerned. ${ }^{167}$ Of course, where the streets, sewers, and water mains of an area have been planned for low density housing, a sudden increase in density can produce a very costly overloading of the facilities. ${ }^{168}$ This problem typically arises in older single-family residential areas in which high density housing is sought for the first time, either in the form of new construction or conversions. It is a rare instance, however, when an undeveloped, fringe suburb can point to a real danger that increased density might overload municipal facilities. ${ }^{169}$

When attempts are made to apply the cost-revenue approach to police, fire, and welfare costs, the results become ludicrous. By taking a survey of existing urban residential areas it is very easy to "prove" that municipal costs for police and fire departments and unemployment are higher in multiple-family areas than in single-family areas; ${ }^{170}$ existing multiple-family districts house most of the lower economic strata of urban society just as they did in the 1930's. But this is no indication that suburban apartment projects would have the same effect. The mere fact that one, ten, or one hundred families live under one roof has no causal relation to the incidence of crime, fire, or unemployment.

Most suburban cost-revenue studies are undertaken by suburban municipalities in order to "'make a case' for a predetermined course

164 See Schmandt, Municipal Control of Urban Expansion, 29 Fordiam L. Rev. 637,645 (1961).

165 See generally 14 McQuillin, Munictpaz Corporations (3d ed. 1950).

186 See Isard \& Coughlin, Municipal Costs and Reyenues Resulting From Urban Growte 10-29 (1957); Wheaton \& Schussheim, The Cost of Municipal SeRVICES in Residential AreAs (1955).

167 Melamed, High-Rent Apartments in the Suburbs, Urban Land, Oct. 1961, pp. 1,6 .

168 Higbe, THe SQUEeze 133 (1960); Fonoroff, The Relationship of Zoning to Traffic-Generators, 20 LAW \& CONTEMP. PROB. 238, 245 (1955).

169 See, e.g., Christine Bidg. Co. v. City of Troy, 367 Mich. 508, 116 N.W.2d 816 (1962).

${ }^{170}$ Cf., e.g., Sullenger, The Social Significance of Mobility: An Onaha Study, 55 AM. J. SocroLOGY 559 (1950). 
of action." 171 They are designed to provide a "scientific basis" for discouraging low and medium priced residential uses. ${ }^{172}$ Ruth Mace, after a comprehensive survey of cost-revenue studies, commented:

Regardless of whether or not their objectives are desirable, most of these "propaganda" studies are characterized by a lack of objectivity, shortcut methods, and conclusions that invariably agree with initial hypotheses. ${ }^{173}$

In other words, anything can be proved with statistics.

2. A once commonly shouted argument, heard less often in the suburbs today, is that apartment buildings cut off light and air. One of the horror pictures painted by the early supporters of zoning was of the bulky, "parasitic" apartment building constructed next to a tiny cottage. ${ }^{174}$ At a time when buildings were constructed right out to the lot lines, this argument had some validity, but proper application of modern zoning controls over bulk would be adequate to prevent this situation. $^{175}$ The strict yard requirements ${ }^{176}$ and height limitations found in most suburban zoning laws make it virtually impossible for a builder to cut off his neighbors' light and air.

3. Another frequently shouted argument is that "the builders of suburban apartments are constructing tomorrow's slums." This is pure speculation. The argument has recently been made that any residential area with a density ratio of more than six dwelling units per acre is a potential slum-unless it happens to be Greenwich Village. ${ }^{177}$ Other commentators have argued that the residents of Park Avenue are living in a slum but are just too dumb to realize it. ${ }^{178}$ In less extreme terms, it is often argued that owner-occupants keep up

171 MACE, op. cit. supra note 158 , at 170.

172 See Barnes \& Raymond, The Fiscal Approach to Land Use Planning, $21 \mathrm{~J}$. of the AM. Inst. of PlanNers 71 (1955).

173 MACE, op. cit. supra note 158, at 170 .

174 Village of Euclid v. Ambler Realty Co., 272 U.S. 365, 394 (1926) ; cf. Williams, supra note 159 , at 323 .

175 See Toll, Zoning for Amenities, 20 Law \& Contenrp. Prob. 266 (1955).

176 See Ledermann, Homebuilding and the Urban Growth Process, J. of the Am. Inst. of Architects, Sept. 1961, p. 33. Some suburbs, on the other hand, have been too lax in their standards, and have permitted apartments of such shoddy construction that they tend to perpetuate the tenement's bad name. Cf. Meyerson, Terrett \& Wheaton, Housing, People and Cities 198-99 (1962).

177 Jacobs, The Death and Life of Great American Ctries 209-10 (1961). Compare: "The frontier was one big rural slum, saved only by the fact that the open spaces were not far away." BURCHARd \& BUSH-BROWN, THE ARCHITECTURE OF ANSERICA 162 (1961).

178 See Kobbe, Housing and Regronal Planning 19 (1941) ; Mumford, The CITY IN History 428 (1961). But compare the observation of Jean Gottmann that "the notion of 'crowding' and the 'feelings' about it appear as an entirely subjective matter." GottmanN, Megalopolis 179 (1961). See also Foote, AbU-LUghod, Foley \& Winnick, Housing Choices and Housing Constraints 123-24 (1960); Denby, EUROPE RE-HOUSED 97 (1938). 
their property better than tenants. ${ }^{179}$ This argument developed during a period of housing shortage when the demand for housing was very high, and landlords had little need to maintain their units. With the present increase in the ratio of housing supply to housing demand, ${ }^{180}$ and the corresponding increase in the vacancy rate, ${ }^{181}$ however, the owner of deteriorated rental housing will find it harder and harder to obtain tenants unless he makes repairs. It is quite possible that we shall soon see rental housing deteriorating less quickly than owned housing. ${ }^{182}$ The owner who lives in his house has less immediate financial incentive to keep the house in repair than the landlord who, except in periods of housing shortage, must maintain his buildings in order to obtain tenants. ${ }^{183}$

A more important factor in the creation of future slums is the basic quality of the housing constructed and the developments planned, ${ }^{184}$ whether multiple- or single-family. ${ }^{185}$ It is ironic to hear a resident of a tract house state that "apartments . . . are not built to last and usually become junk in fifteen years," 186 when there are so many examples of "suburban slums" consisting of singlefamily shacks located in outlying areas. ${ }^{187}$ These areas may be

179 See Williams, supra note 159 , at 347.

180 HHFA Administrator Weaver, in an address before the National Association of Real Estate Boards in Detroit, recently stated that "the housing squeeze is all but over except for the lowest-income families." Houston Chronicle, Nov. 16, 1962, $\S 1$, p. 18 , col. 4 (final ed.).

181 In 1962, at any time, $7.4 \%$ of the rental housing units in the nation were vacant. HHFA, HousING STATISTICS 10 (March 1963).

182 See Clemons v. City of Los Angeles, 36 Cal. 2d 95, 222 P.2d 439 (1950), in which the court upheld a restriction preventing the owner of a bungalow court from selling off individual bungalows. The restriction was justified on the ground that the property would not be as well maintained if separately owned. Cf. Shapiro v. City of Baltimore, 186 A.2d 605 (Md. 1962). But see Beers v. Board of Adjustment, 75 N.J. Super. 305, 311, 183 A.2d 130, 133 (App. Div. 1962).

183 To the extent that the Negro continues to constitute a separate housing market in which the demand exceeds supply, this hypothesis will not apply in Negro areas. Cf. Westfield v. City of Chicago, 187 N.E.2d 208 (IIl. 1962). While that case did not refer to the racial factor, the authors believe, based on their personal knowledge of Chicago, that the case supports the proposition stated.

184 See Lovelace, "Urban Sprazll" Need Not Be a Tragedy, 51 LANDSCAPE ArchiteCtuRe 230 (1961); Aronovici, Zoning and the Home, 155 Annals, pt. 2, pp. 145,150 (May 1931).

185 A 103-house subdivision was constructed in 1955 in Pomona, California. The crackerbox houses, priced at $\$ 10,000$ each, did not sell. By 1959 , only $40 \%$ were occupied, the remainder having "fallen prey to vandalism and decay." An urban renewal project was underway for the subdivision. See Four-Year-Old Tract Undergoes Urban Renewal To End Blight, House \& Home, Jan. 1960, p. 82.

186 Des Plaines (IIl.) Suburban Times, Dec. 6, 1962, p. 13, col. 5.

187 Abrams, The Future of Housing 23-28 (1946); Banfield \& Grodzins, Government and Housing IN Metropolitan Areas 24 (1958); see GotTManN, Megalopolis 407 (1961); cf. Note, Suburban Renewal in Pennsylvania, 111 U. PA. L. Rev. 61, 62-65 (1962).

In Brasilia, the new capital of Brazil, the planners made no provisions for slums. Though the capital has been in existence for only three years, 142,000 of its 190,000 people already live in shantytown suburban slums on the outskirts of the city. Landscape, Autumn 1962, pp. 24, 25. 
uglier, ${ }^{188}$ more expensive, ${ }^{189}$ and more annoying ${ }^{190}$ than a typical high-density urban slum. Moreover, the cost of rehabilitating or clearing low-density areas might be considerably higher per unit of population than the cost of clearing high-density areas. ${ }^{191}$

4. "Apartments will reduce property values." This argument, frequently voiced by owners of surrounding property, contains an element of irony. Land values in most existing apartment areas are very high. ${ }^{192}$ But even if the fact that the proximity of apartments often adds a speculative value to the surrounding land is ignored, there is little evidence that an apartment per se will detract from the value of surrounding land. ${ }^{103}$ The increased population housed by apartments will increase the value of commercial property in the neighborhood. Moreover, the type of high grade multiple-family housing now being constructed by reputable builders may well increase the desirability of the entire community. Experience with modern types of housing is so limited that most appraisers would hesitate to make a firm prediction as to the effects of multiple-family dwellings on property values.

5. If no "hard" issues are available, suburbanites take refuge in the "character of the community." All the charm of his homogeneous neighborhood would disappear, he claims, if apartments were permitted. ${ }^{194}$ It is hard to argue with an esthetic judgment that is so purely subjective. If one believes that character is found only in

188 See Blight-Suburban Style, Urban Land, May 1955, pp. 1, 3-4.

189 See Cook County Housing Authority, Robbins, Illinors, an Imimediate Problem (1947).

190 As long as the slum was contained in a small congested mass within the old center of the city, most of the middle- and upper-income inhabitants of the urban area could live out their lives without being acutely aware of its existence. As the slum-dweller has taken to less dense living, however, the manifestations of his existence have not been quite so easy to suppress.

Vernon, The Myth and Realtty of Our Urban Problems 22 (1962); cf. BurCEARd \& BUSH-Brown, op. cit. supra note 177, at 268-70.

101 Rehabilitation programs may be more feasible in high density areas. But see Note, sipra note 187, at 102-03 (1962).

102 See notes 91, 93 supra; cf. note 25 supra.

193 It is difficult to generalize whether this added speculative value will compensate for a possible loss in value resulting from the proximity of apartments. See, e.g., Shelger, Technique of Analyzing Residential Areas, in AMrRICAN INST. OF REAL Estate Appraisers, Real Estate Appraisal Practice 51, 57 (1958).

104 This same argument is often heard from the British suburbanite. See 4 Ministry of Housing and Local Government, Setected Planning Appeals 4 (2d ser. 1962), in which the local legislative body argued as follows:

Very tall buildings were best sited in central built-up areas rather than in small towns, where they would be incongruous and out of scale. Dorking was a small country town in pleasantly rural surroundings. . . . The high buildings could not fail to appear as prominent and incongruous features from many points. In their effect upon the estate itself they would violate the privacy of neighbouring dwellings and overpower a number of houses still to be built. 
suburbs containing nothing but single-family houses, who can disprove it-de gustibus non est disputandum. But the suburbanite should note that in the opinion of many of the best architects a mixture of dwelling types is desirable for esthetic reasons. ${ }^{195}$ Anyone who chooses the tract house as an esthetic ideal must expect that his judgment will be questioned.

\section{B. The Whispered Reasons}

When community character is used as a shouted argument, it often bears close resemblance to the arguments that are usually whispered. Is the word "character" accompanied by a knowing wink? Do the listeners all understand that the reference is not to the physical characteristics of the buildings, but to the characteristics of the people who will occupy them? ${ }^{196}$ Will a foreign accent strike a discordant note in suburbia's barber shop sing? ${ }^{197}$ Will the compact car which accompanies the apartments detract from the "character" of the local traffic pattern?

Few suburbs have been as overt in defining their character as Grosse Point, Michigan. In that community, each nationality was assigned a specific rating which, when computed mathematically together with the applicant's other social and economic characteristics, determined whether he had enough character to enter the leafy gates of Grosse Pointe. ${ }^{198}$ Bigotry is becoming an exact science.

In the more genteel suburbs, the prejudices of the populace are conveyed in whispers and by innuendo. Basically, there are three arguments.

1. "Apartments will attract persons of the lower classes . . . ." It is unnecessary to inquire into the propriety of this argument ${ }^{199}$ to

195 See, e.g., Wright, The Living City 170 (1958).

196 See the definition of neighborhood character in MAY, THE Valuation of Residential REAL ESTATE 91 (1953): "The word 'character' means the economic and social as well as the moral qualities of the neighborhood's inhabitants."

197 Suburbia had its Victorian counterpart:

The population of Evanston includes many well-known Chicago merchants, and bears the reputation of being of the best character generally. The air of intense respectability which clothes the average Evanstonian is relieved by his devotion to music, to literary evenings, to the work of the gospel. The people are most homogeneous, and scarcely an evening passes but is celebrated by some gathering at which the feast of reason and the flow of soul proceed uninterruptedly along.

Chamberlin, Chicago and Its Suburbs 382 (1874).

198 N.Y. Times, April 24, 1960, $\$ 4$ (News of the Week in Review), p. 4.

$199 \mathrm{On}$ the constitutionality of economic segregation see Williams, Planning Iaw and Democratic Lizing, 20 LAw \& Contemp. PROB. 317, 343-48 (1955). Regarding its wisdom see BANFIELD \& GRodzLNs, op. cit. supra note 187, at 71-92.

A former village planning director for Oak Park, Illinois, commented that much of the opposition to a proposed high rise apartment project in Oak Park came from people who feared that any high rise apartment would pave the way for large government housing projects. Chicago Sunday Tribune, Jan. 28, 1962, \& 8, p. 3, col. 3. 
show clearly that there is in fact no direct relation between social class and number of families per structure. Some of the "best neighborhoods" consist almost entirely of multiple-family housing, and some of the "worst" are the single-family slums. It is the cost of housing that is the prime determinant of the social status of the occupants; ${ }^{200}$ cheap housing will attract the lower income groups while expensive housing will not. ${ }^{201}$

2. "Multiple-family housing will bring in a lot of transients who have no interest in the neighborhood." Traditionally, residents of rental housing have had a higher mobility ratio than owner-occupants. ${ }^{202}$ It would seem logical that persons and families who foresee the necessity of another move in the near future would choose a form of tenure which can easily be terminated. ${ }^{203}$ The short-term lease has this advantage. When a house is to be sold, however, a buyer must be found, and the transfer of title is risky, time-consuming, and expensive. ${ }^{204}$ However,

200 In his studies of social stratification, Lloyd Warner experimented with many complicated classifications of housing types in an attempt to formulate an index of status characteristics. After many years of effort, Warner, his collaborators, and other sociologists eventually decided to use the following scale in their index:

1. Excellent houses

2. Very good houses

3. Good houses

4. Average houses

5. Fair houses

6. Poor houses

7. Very poor houses

Warner, MEERER \& Eelis, Social Class iN America 123 (1949). Apartments were found in all categories. Id. at 150 . This demonstrates that while bigotry may pretend to be an exact science, sociology, with laudable honesty, makes no such claims.

201 The desire to keep out the lower classes is the prime motive of suburbanites favoring large lot zoning. See Coke \& Liebman, Political Values and Population Density Control, 37 LaND Economics 347, 354 (1961). There is reason to doubt, however, whether large lots actually achieve this result. $C f$. id. at 357-61; URBAN LAND INstitute, The Effects of Large Lot Size on Resmential Deveioparent (Technical Bull. No. 32, 1958). See also the statement submitted by Gerald D. Lloyd, Chairman, State Legislative Committee, Builders Institute of Westchester and Putnam Counties, to the New York State Joint Legislative Committee on School Financing at its hearing on February 8, 1961:

Since land value bears a close relationship to the population density assigned to it, the surfeit of large lot zoning has artificially lowered land values to the point where even the builder of a cheap house can afford a large sized plot. Many of our suburban communities still have large areas of unused existing road frontage-and thus, even in cases where planned development is artificially discouraged, population growth nevertheless takes place on these existing road frontages and on distress parcels thrown on the market at exceedingly low prices.

202 Winnick, Rental Houstng: Opportunities for Private Investarent 9 (1958). See generally Rossi, Why Familmes Move (1955).

203 Foote, Abu-Lughod, Foley \& Winnick, Housing Choices and Housing CONSTRATNTS 143 (1960).

204 See generally DeAN, Home OwNERshIP: Is IT SoUnd? (1945). 
in the past fifteen years people have been encouraged to purchase rather than rent housing even though they know that they will not remain long. Today the mobility rate of owner-occupants is much closer to that of tenants than it has been in the past. ${ }^{205}$ The alarmingly high and continually increasing rate of defaults on single-family mortgages ${ }^{206}$ is also evidence that the supposed stability and permanence of singlefamily homeownership partakes at least partially of mythology.

It is dangerous to make many generalizations concerning questions of social class or transiency, in view of the wide variety in types of multiple-family housing now being built in the suburbs. ${ }^{207}$ It is difficult to predict with accuracy the future stratification and mobility of the occupants of new low-rise condominiums, of suburban high-rise cooperatives, ${ }^{208}$ or of large multiple-family projects for elderly Presbyterians. ${ }^{209}$ Suburbanites who condemn apartment dwellers across the board remember only the urban "tenement" from which many of them only recently departed. They fear that the occupants of the proposed new suburban apartments may be those same city people that the suburbanites thought they had left behind. A suburban alderman summed the matter up in this fashion: "[T]he residents of Pleasant Manor [subdivision] came from Chicago to escape apartments, and purchased lots in Des Plaines with the belief that the integrity of their singlefamily neighborhood would not be violated." 210

Most suburbanites fail to appreciate the remarkable proliferation in types of multiple-family housing now available. The multiple-family dwelling is not a standardized unit which attracts a standardized tenant. $^{211}$ This new variable may worry homeowners such as the one who

205 Foote, ABU-LUghod, Foley \& WiNNICK, op. cit. supra note 203, at 144; Meyerson, Terrett \& Wheaton, Housing, People and Citres 89 (1962).

208 See note 114 supra.

207 Kelly, Design and the Production of Houses 122-23 (1959); Garden Apartments and Townhouses, House \& Home, Feb. 1963, p. 85.

208 The chairman of the planning commission of a large Chicago suburb was quoted as follows: "Personally, I like the high rise apartments. They cater to less transient tenants than you would find in the smaller buildings." Chicago Sunday Tribune, Feb. 11, 1962, \& 8, p. 14, cols. 1-6.

209 For examples of the variety in types of new housing for the elderly see American Soc'y of Planning Offictals, Planning for an Aging Population (Planning Advisory Serv. Information Rep. No. 148, July 1961).

210 Des Plaines (Ill.) Suburban Times, Feb. 21, 1962, p. 1, col. 5.

211 Compare Jacobson v. Village of Wilmette, 403 Ill. 250, 256, 85 N.E.2d 753, 756 (1949) :

The village of Wilmette is one of the north shore suburbs of Chicago, lying between Evanston and Kenilworth and has a population of a little over 17,000 composed largely of professional men, advertising men, business men, executives of manufacturing concerns, people who are employed in banks, schools and various types of business in town. A small percentage of the total population live in multiple-family dwellings and the village has a territory zoned for such dwellings.

with Quintini v. Mayor of City of Bay St. Louis, 64 Miss. 483, 490, 10 So. 625, 628 (1887): 
objected to new apartments because "You just never know what kind of people will move into that kind of development." 212

3. "If we let them build apartments they'll be renting to Negroes " 213 Although there seems to be little basis for it, this argument is often heard. Negroes have typically entered formerly white neighborhoods by purchase rather than by rental. ${ }^{214}$ Past experience, however, may not be relevant in view of two new weapons designed to assist Negroes in obtaining housing. State open-occupancy laws may have more impact on multiple-family housing ${ }^{215}$ than on single-family housing, if, as is the case in some states, ${ }^{216}$ sales of single-family dwellings are exempted from the laws. Conversely, the President's executive order restricting discrimination in federally assisted housing may have greater impact on single family housing than on multiple-family housing, since a higher proportion of single-family housing receives federal assistance. ${ }^{217}$ Lack of experience with these laws and rules makes prediction in this area difficult.

\section{Subconscious Arguments}

The third category of the suburban arguments consists of those that are not even whispered. The only reason they can be attributed to the suburbanite is that they are argued for him, against him, and about him. These we will call the subconscious arguments. In the last fifteen years, few problems have held as much interest for both professional and amateur social psychologists as the problem of why the suburbanite acts the way he does. ${ }^{218}$ Probing the slippery suburban subconscious has proved tricky, and it would be overly presumptious

The law can know of no distinction between citizens because of the superior cultivation of the one over the other. It is with common humanity that legislatures and courts must deal, and that use of property which in all common sense and reason is not a nuisance to the average man cannot be prohibited because repugnant to some sentiment of a particular class.

Has our judicial measure of "reasonableness" progressed in half a century?

212 Elmhurst (III.) Press, May 1, 1962, p. 2, col. 7.

213 Suburban antipathy to cheap housing often conceals a fear of Negro infiltration; few Negroes can afford expensive housing. MCENTIRE, RESIDENCE AND RACE 107 (1960). "In effect, economic segregation is not only the easiest but also the most effective form of racial and ethnic segregation." Williams, Planting Law and Democratic Living, 20 Law \& CoNTEMP. PROB. 317, 330 (1955).

214 See Advance Mortgage Corporation, Mmwestern Minority Housing MarKETS 4 (1962).

215 See Avins, Anti-Discrimination Legislation as an Infringement on Freedom of Choice, 6 N.Y.L.F. 13, 20 (1960).

216 See Saks \& Rabkin, Racial and Religious Discrimination in Housing: $A$ Report of Legal Progress, 45 IowA I. REv. 488, 522-23 (1960).

217 In 1961, the FHA insured loans on 376,248 single-family dwelling units compared to 59,367 multiple-family dwelling units. 1961 HHFA ANN. REP. 39, 42.

218 "Suburbia has become the scapegoat of our era." Gans, Book Review, 28 J. OF THE AMr. INST. OP PLANNERS 47, 48 (1962). 
of mere lawyers to pass judgment. A complete picture, however, does require that we at least list some of the deeper reasons that have popularly been thought to underlie the suburbanite's rejection of, among other things, multiple-family housing. Some commentators have equated the suburban attitude of grass-roots democracy ${ }^{219}$ to the simple agrarian life, ${ }^{220}$ far removed from urban vice and squalor. Others have pointed to basic emotional insecurities ${ }^{221}$ found in-and perhaps caused by-suburbia. ${ }^{22}$ These insecurities generate a fear of downward social mobility resulting in strong antagonism to any of the symbols that the suburbanite associates with the feared groups. ${ }^{223}$

Still other critics cite the importance of children ${ }^{224}$ in suburbia. They call suburbia a "pastel-colored playpen world," 225 organized on matriarchal lines, in which the child is King and his mother Regent. Other research, still in an embryonic state, has pointed up the importance of the physical location of buildings, yards, and entrances in molding local social life, ${ }^{228}$ an attitude which may subconsciously affect attitudes toward new housing types.

All of these reasons-shouted, whispered, and subconscious-are vague and variable unknowns deserving extensive research. This summary is intended only to demonstrate that suburban antipathy to apartments does exist, and that the real reasons behind the antipathy often lie in areas traditionally outside the scope of governmental control.

\section{The Current Judicial Approach}

Meanwhile, back in the courts, the old litany drones on. The segregation of the apartment building, since its initial acceptance by

210 See Wood, Suburbia 19497 (1958).

220 [T] .. . toward the development of suburban towns. . . Such a new distribution of population combines at once the open air and spaciousness of the country with the sanitary improvements, comfort and associated life of the city.

Webere, The Growth of Cities in the Nineteenth Century 458-59 (1899); see Bodek, How and Why People Buy Houses 23-24 (1958); Gottmann, MegaLOPOLIS 390 (1961).

221 See Beyer, Housing: A Factual Analysis 212 (1958); Strauss, IMages of the AMERICAN CITY 236 (1961); Wirth, Sociological Factors in Urban Design, in COMMUNity LIFE AND Social PolicX 284, 286 (1956).

222 Seeley, Star \& Looseley, Crestwood Heights (1956); Gordon, Gordon \& Gunther, The Split-Leved Trap (1960). But see Gans, Suburbs and Planners, Landscape, Autumn 1961, p. 23; Riesman, Some Observations on Lewis Munford's "The City in History," 1962 WASH. U.L.Q. 288, 292-93 (1962).

223 Cf. Bettel heim \& Janowitz, Dynamtcs of Prejudice $65-70$ (1958).

224 See generally Keats, The CRAck IN the Picture Window (1956). See citations in FOOTE, ABU-LugHOD, FOLEY \& WINNICK, op. cit. supra note 203, at 194. 225 HigBeE, The SQUEeze 89 (1960).

226 Festinger, Schachter \& Back, Social Pressures in Informal Grouts (1950); Whyte, The Organization MaN 330-49 (1956). 
the judiciary in the 1920's has become an unspoken premise. Attorneys who represent developers seeking to erect apartments rarely question the general principle of apartment segregation; rather, they question only the application of the principle to their particular fact situation. Consequently, the basic issue of the validity of zoning distinctions based solely on dwelling type is rarely brought to the attention of the courts. Piling unexamined premise on unexamined premise, the courts sometimes reach absurd results. The Maryland Court of Appeals, for example, as a result of a strange series of cases, allowed a municipality to prohibit separately owned row houses in areas where rental "garden apartments" were permitted. ${ }^{227}$

When a court wishes to reaffirm the validity of segregation by dwelling type, it often does so with very few words. It will commonly note that the principle is "settled," 228 throwing in a reference to Euclid ${ }^{229}$ or a string citation. ${ }^{230}$ Courts will often define the word "residential" as applicable only to single-family houses, relegating apartment dwellers to nonresident status in some purgatory of unknown classification. $^{231}$ Occasionally, however, a court will feel obligated to add some reasoning to the authority of precedent. In a few cases, the reasons applicable to nineteenth century tenements are merely repeated 232 -apartments "are not inherently benign," ${ }^{233}$ they cause "congestion" 234 and "increased risks and annoyances of various natures," 235

227 Shapiro v. Baltimore, 186 A.2d 605 (Md. 1962) ; see Renz v. Bonfield Holding Co., 223 Md. 34, 158 A.2d 611 (1960); Windsor Hills Improvement Ass'n v. Mayor of Baltimore, 195 Md. 383, 73 A.2d 531 (1950) ; Norwood Heights Improvement Ass'n v. Mayor of Baltimore, 191 Md. 155, 60 A.2d 192 (1948); Akers v. Mayor of Baltimore, 179 Md. 448, 20 A.2d 181 (1941) ; cf. Clemons v. City of Los Angeles, 36 Cal. 2d 95, 107-15, 222 P.2d 439, 447-51 (1950) (dissenting opinion).

228 Wilkins v. City of San Bernardino, 29 Cal. 2d 332, 337, 175 P.2d 542, 547 (1946) ; see Guaclides v. Borough of Englewood Cliffs, 11 N.J. Super. 405, 412-13, 78 A.2d 435, 439 (1951).

229 Northwood Properties Co. v. Royal Oak City Inspector, 325 Mich. 419, 39 N.W.2d 25 (1949) ; Hagans v. District of Columbia, 97 A.2d 922 (D.C. Munic. Ct. App. 1953).

230 Jennings' Appeal, 330 Pa. 154, 160, 198 Atl. 621, 623 (1938) ; Collins v. Board of Adjustment, 3 N.J. 200, 208, 69 A.2d 708, 712 (1949).

231 See, e.g., Connor v. Township of Chanhassen, 249 Minn. 205, 210-11, 81 N.W.2d 789, 794-95 (1957).

The word "home" is also frequently applied only to single-family dwellings, as in the name of the Housing and Home Finance Agency. One can only be surprised that the name is not the "Home and Housing Finance Agency."

232 See, e.g., Frankel v. City of Denver, 363 P.2d 1063, 1066 (Colo. 1961); LaSalle Nat'l Bank v. Village of Skokie, 26 Ill. 2d 143, 147, 186 N.E.2d 46 (1962);

Rodgers v. Village of Tarrytown, 302 N.Y. 115, 130, 96 N.E.2d 731, 738 (1951) (dissenting opinion).

233 Fanale v. Borough of Hasbrouck Heights, 26 N.J. 320, 325, 139 A.2d 749, 752 (1958).

234 Anderson v. County of Cook, 9 IIl. 2d 568, 571, 138 N.E.2d 485, 487 (1956);

Wesemann v. Village of LaGrange Park, 407 Ill. 81, 87, 94 N.E.2d 904, 908 (1950). 235 Antrim v. Hohlt, 122 Ind. App. 681, 687, 108 N.E.2d 197, 199 (1952); see Jacobson v. Village of Wilmette, 403 III. $250,257,85$ N.E.2d 753, 757 (1949). 
while single-family residence districts tend "to promote and perpetuate the American home and protect its civic and social values." ${ }^{238}$ Other courts point to the "deleterious," 237 "detrimental," 238 or "depreciatory" ${ }^{239}$ effect of apartments on "high-type" ${ }^{240}$ single-family uses, without further specification. ${ }^{241}$ Still others justify the exclusion of apartments from single-family housing areas because of the supposed harm done to neighborhood property values, without examining whether values will really decline and, if so, why. ${ }^{242}$

Those courts which have articulated more meaningful reasons usually have concerned themselves with questions relating to density. The Pennsylvania Supreme Court recently justified distinctions between dwelling types because "each type of residential development requires different supplies of public facilities." ${ }^{243}$ "The regulation of density," said the Illinois Supreme Court, "is a legitimate object of the police power." 244 But the courts have not yet faced the problem of the developer of multiple-family dwellings who offers to maintain the same density as required for single-family houses. The day is soon coming when the courts will have to decide the crucial questions: (1) Are there any valid criteria for excluding multiple-family units other than density? (2) If density is a fair basis for governmental control, what political unit should determine the proper density? (3) What standards should be used in determining proper density?

\section{Two Case Studies}

The issues can be brought into focus by setting out two hypothetical cases. ${ }^{245}$ Each begins with a proposal to construct multiplefamily dwellings in an area zoned to permit four single-family detached

238 Church of Jesus Christ of Latter-Day Saints v. City of Porterville, $90 \mathrm{Cal}$. App. 2d 656, 660, 203 P.2d 823, 825 (1949).

237 Fanale v. Borough of Hasbrouck Heights, 26 N.J. 320, 325, 139 A.2d 749, 752 (1958).

238 Jacobson v. Village of Wilmette, 403 I11. 250, 259, 85 N.E.2d 753, 758 (1949).

239 Trendel v. County of Cook, 27 IIl. 2d 155, 188 N.E.2d 668 (1963). (1944).

240 Dundee Realty Co. v. City of Omaha, 144 Neb. 448, 453, 13 N.W.2d 634, 637

241 Something about this topic brings out a judge's penchant for pithy expletives. Thus the Georgia court referred to apartments as "undesirable encroachments." Lewenstein v. Brown, 200 Ga. 433, 440, 37 S.E.2d 332, 336 (1946).

242 Sullivan v. Anglo-American Investment Trust, Inc, 89 N.H. 112, 116, 193 At1. 225, 227 (1937).

243 Best v. Zoning Bd. of Adjustment, $393 \mathrm{~Pa} .106,118,141 \mathrm{A.2d} 606,613$ (1958); see Heller v. Zoning Bd. of Adjustment, 404 Pa. 8, 171 A.2d 44 (1961).

244 Exchange Nat'1 Bank v. County of Cook, 25 Ill. 2d 434, 441, 185 N.E.2d 250, 254 (1962). See also Wesemann v. Village of LaGrange Park, 407 Ill. 81, 88, 94 N.E.2d 904,908 (1950).

245 These cases are intended to be purely hypothetical. They are not based on any one of the many such disputes in which the authors have been involved, but the authors believe that they are characteristic. 
dwelling units per acre. In both cases, the property-a five-acre tractis located on the edge of an outer suburb, substantially all of whose 12,000 residents reside in detached dwellings. A few apartment units are located above retail stores in the business district, and within a block of the commuter train station there are six multi-unit buildings located between the business district and single-family residences. The subject property abuts vacant land to the west. Postwar single-family dwellings are located across improved secondary streets to the north, east, and south. In 1940, the population of the community was 4,500. Between 1940 and 1960, the assessed valuation of the property in the public school district dropped from $\$ 35,000$ to $\$ 18,000$ per student.

\section{A. Case $A$}

The developer seeks to construct five buildings, each containing four row house units grouped around a substantial amount of open space. ${ }^{248} \mathrm{He}$ may rent or sell the units, depending on the market. He will assure the continuation and maintenance of the common open space, and will comply with the setback, height, and off-street parking requirements of the single-family district.

Case $A$ involves no change in density. The developer accepts the four-family per acre standard, but wishes to group his dwellings. Although these circumstances may not sound as familiar as the usual multiple-family proposal which involves an increase in density, clustering is becoming increasingly popular with developers. ${ }^{247}$

Case $A$ presents an issue which should give the courts the greatest difficulty if they will only trouble to push through the clichés and fetishes which for four decades have acted as a moat for the detached singlefamily dwelling. The community which wishes to reject this proposal cannot do so by invoking any of the "hard" arguments of public wel-

246 Suburban zoning boards sometimes object to regulations which would permit apartments to be grouped around substantial open space on the ground that the developer might later request a variation to build on the open space. See, e.g., Des Plaines (Ill.) Suburban Times, Feb. 8, 1962, p. 1, cols. 6-8. Similar objections stymied the imaginative plans of Norman Blankman and Victor Gruen for a cluster subdivision in which buildings would have occupied only six percent of the 516-acre Whitney estate in Old Westbury, Long Island. See Buildings for the Suburbs, Architectural Forum, Jan. 1961, p. 97; 107 CoNG. Rec. 1778-79 (daily ed. Feb. 9, 1961). Objections of this type point up the need for controls which will insure the continuity and maintenance of the open space. Cf. Coffin v. Old Orchard Dev. Corp., 186 A.2d 906 (Pa. 1962).

247 See Urban Land Institute, New Approacaes to Resmentiar Development (Technical Bull. No. 40, Jan. 1961). See also By-passed Land, House \& Home, Feb. 1957, p. 108; Garden Apartments and Tozmhouses, House \& Home, Feb. 1963, p. 85; Feld, Chuster Garden Subdivision, American City, July 1959, p. 109 ; AMERICAN Soc'y of Pranning Officials, Cluster Subdrvisions (Planning Advisory Serv. Information Rep. No. 135, June 1960); Philadelphia Housing Authority, Suburbia Reshaped: The Case for Flexible Zoning Controls (1960); Urban LAND INSTITUTE, The CoManunity BuInders HaNdBook 91-102 (1960). 
fare. The proposal cannot increase the burden on public services; in fact, it is arguable that it may involve less cost for public services than would the same number of dwellings, each on its own lot. If, by definition, there is no increase in the number of families, there should be no increased demand on the fire department, police, or public health services. Sewer and water demands will be the same whether the project is permitted or separate dwellings are built on their own lots. Likewise, the impact upon traffic should not be significantly different. Nor can that old bugaboo-the crowded public school classroom-be placed in issue. The rubric of the Euclid opinion that "the coming of one apartment house is followed by others, interfering by their height and bulk with the free circulation of air and monopolizing the rays of the sun which otherwise would fall upon the smaller homes, and bringing, as their necessary accompaniments, the disturbing noises incident to increased traffic and business" ${ }^{248}$ has no relevance to Case $A .{ }^{249}$

What then is the legal basis for a denial of the request to construct buildings with common walls between units rather than detached houses with twelve-foot side yards? The only defense that has a color ${ }^{250}$ of plausibility is that a change in dwelling type will have a detrimental effect upon the economic value of single-family detached homes in the neighborhood. People buy into a neighborhood of detached dwellings, so the theory goes, because they seek the intangible values of security and status which a cohesive, homogeneous neighborhood provides. These are, it is maintained, "legitimate" values; they are reflected in sturdy land values, thus securing the tax base. Hence, the community has a real interest in furthering these neighborhoods by public law. ${ }^{251}$

248 Village of Euclid v. Ambler Realty Co., 272 U.S. 365, 394 (1926).

249 "Density Zoning," under which no distinction is made between types of residential uses and only density is regulated, has often been advocated. See, e.g., Gallion, The URban PatTern 360 (1950); Urban LAND INSTITUTE, Density ZoNING (Technical Bull. No. 42, July 1961); Goldston \& Scheuer, Zoning of Planned Residential Developments, 73 HARV. L. REV. 241 (1959) ; Lovelace, Zoning for LargeScale Developments, 14 ZoNING DIGEST 129-34 (1962). Compare Chrinko v. South Brunswick Planning Bd., 187 A.2d 221 (N.J. Super. 1963), with Hiscox v. Levine, 31 Misc. 2d 151, 216 N.Y.S.2d 801 (Sup. Ct. 1961).

The 1916 New York City ordinance used "density zoning." See BASSETT, ZoNing $63-64$ (1936). But see Barker v. Switzer, 209 App. Div. 151, 205 N.Y. Supp. 108, appeal dismissed, 238 N.Y. 624, 144 N.E. 918 (1924). The 1957 Chicago ordinance was among the first of the contemporary ordinances to introduce the density concept into six of the eight residential districts. See Babcock, The New Chicago Zoning Ordinance, 52 Nw. U.L. Rev. 174, 178-81 (1957).

250 Aesthetics might be a colorable argument on which to restrict dwelling type in historic or scenic areas such as the Vieux Carre in New Orleans, but the average suburb has no legitimate claim against apartments on aesthetic grounds. Even if we make the assumption that the typical suburb has some beauty to be protected, and that this is a valid public purpose, certainly the apartment per se will not destroy the beauty of the suburb.

251 "On analysis the primary objects of zoning are found to be, not so much the protection of public health and safety, as the protection of the value and usefulness of urban land . . . ." Landels, Zoning: An Analysis of its Purposes and its Legal 
There are, however, at least two difficulties with this argument. First, it would appear to require persuasive evidence that a change in dwelling type without an increase in density will have an adverse impact on property values. Second, even if such a result could be substantiated, this theory assumes that the cause of the decline in property values-adverse reaction to a change in dwelling type-is a legitimate basis for public action. ${ }^{252}$

All the "evidence" we have on the adverse impact of a change of dwelling type on property is, to put it generously, speculative. The customary, though dubious, practice in zoning cases of calling neighbors to voice their objections would undoubtedly reach its zenith in Case $A$ because the municipality has little else on which to bottom its case. The appraiser may offer an opinion that the introduction of row houses will cause a decline in the value of neighboring detached houses, but the basis for his opinion will rarely be more than a hunch about what motivates people to buy. The concept of clustering dwellings without change in density is so new that any testimony based upon traditional thinking about multiple-family housing, based as it is on increased densities, is probably irrelevant. At the very least, the judge who has to listen to this Delphic testimony should-provided he can shake memories of a boyhood spent in a gabled dwelling on an elmlined suburban street-challenge the glib ${ }^{253}$ type of answer this inquiry prompts. The arguments against the housing proposed in Case $A$ are no more than a repetition of conclusions about "tenements" which may have had validity in a Boston or a Chicago of 1890 , but which need reexamination in the suburbs of the 1960's.

The plea to protect property values is in this case just another and perhaps more acceptable way of arguing the "character" of a neighbor-

Sanctions, 17 A.B.A.J. 163, 165 (1931). See also Sayre, Aesthetics and Property Values: Does Zoning Promote the Public Welfare?, 35 A.B.A.J. 471 (1949). The Pennsylvania Supreme Court seems willing to accept this argument. Best v. Zoning Bd. of Adjustment, $393 \mathrm{~Pa} .106,116,141$ A.2d 606, 612 (1958).

252 As with many aspects of zoning, it has been said before :

The pioneers in the field of American city planning were not thinking primarily of zoning laws as a means of stabilizing property values, although it was confidently hoped and expected that such stabilization would ensue. They were thinking of a zoning ordinance in the same general sense as a traffic ordinance as a means of promoting the welfare of the whole community and guilding its growth along orderly lines. . . Zoning, however, quickly became popular. . . The rank and file of the people are coming to look upon it as merely a matter of maintaining or increasing property values.

Munro, A Danger Spot in the Zoning Movement, 155 Annals, pt. 2, pp. 202, 203

(May, 1931).

253 Take a drive around your community. If there are low cost housing projects surrounding your neighborhood, look at them carefully. There isn't a fence high enough to preserve your way of life, protect the value of your home or relieve you of the future tax burden these slums represent.

Tebber, The Slum Makers 82 (1963). 
hood or community. If, in this setting, "character" is fairly defined as "a trait or sum of traits conferring distinctiveness," ${ }^{254}$ the consequences of the introduction of low-density, multiple-family housing may be accurately stated, but they may also be irrelevant. It should be remembered that Webster's Dictionary also defines "character" as a "cabalistic, magical or astrological sign or symbol." 255 The protection of community character, like the protection of property values, is a derivative argument. A reviewing court should isolate the factor or factors that are responsible for the purported injury, and determine whether the control of such factors is a proper sphere of governmental regulation.

When the argument is made that property values will be affected, what is meant is simply that some factor is present which some people may dislike, and which may therefore tend to result in a net reduction in the number of people interested in buying property in the area affected-thus tending to push values down. The real question is always a simple onewhat is the factor which is involved? Some factors which affect property values (or which are thought to do so) are legitimate subjects for public regulation, by zoning or otherwise; others are not. For example, the invasion of factories and the movement of Negroes into a residential neighborhood both may be thought to affect property values. Yet one is obviously a proper subject for zoning protection, while the other is not. The fact that property values may be affected gives reason to look into the situation, but by itself tells nothing about whether governmental protection is appropriate. ${ }^{256}$

When racial discrimination is involved, it is clear that civil rights must prevail over the wish of the transient majority in an existing suburb to live in a particular environment. ${ }^{257}$ But there are other less obvious and less dramatic rights which, in Case $A$, may also be entitled to override suburbia's desire to be free of multiple-family dwellings.

The boom in new apartments, though in part caused by tax and market incentives, nevertheless represents a real demand for a wide variety of new types of dwelling units. This demand is caused not by

254 Webster, New International Dictionary 451 (2d ed. 1960).

255 Ibid. See, e.g., the testimony of the planning consultant in Hamer v. Town of Ross, 22 Cal. Rptr. 686, 690 (Ct. App. 1962):

Looking at the town and studying its zoning ordinance, I have the strong feeling that the people in the town of Ross want what we might call a high type of residential community, single family home residential community. I get that feeling from looking at the town and from reading its ordinance.

256 Williams, Planning Law and Democratic Living, 20 LAw \& ConTEMr. ProB. 317, 334 (1955); cf. Savage, Land Planning and Democratic Purposes, 34 Notre Dame Law. 65, 71-75 (1958).

257 Buchanan v. Warley; 245 U.S. 60 (1917); see In re Lee Sing, 43 Fed. 359 (N.D. Cal. 1890) ; cf. Gomillion v. Lightfoot, 364 U.S. 339 (1960). 
mere esthetic preferences, such as those which motivate suburbia's desire to exclude apartments, ${ }^{258}$ but by larger social and economic developments over which the participants have no control. The tremendous jump in the number of the elderly and of young married couples, the dispersal of industry and jobs to the suburbs, the increased congestion of transportation in the central core, have all created a demand for housing which does not fit into the traditional suburban mold. The people who need this housing do not make up such a clearly defined, sympathy-evoking class as a particular ethnic group. Nevertheless, they, too, are entitled to certain rights. If the suburbs are going to exclude them, they are entitled at the very least to a showing by the suburbs of valid legal reasons to support the exclusion. Such a burden of proof is not too much to ask. In Case $A$, the burden could not be met.

\section{B. Case B}

On an identical five-acre tract of land in the same suburb as in Case $A$, a developer seeks to erect five two-story buildings, each containing twelve apartments. The size of the apartments would vary from efficiencies to three bedrooms, but most would contain one or two bedrooms. The developer offers to meet the height and setback standards, but seeks to increase the density to permit twelve dwelling units per acre.

In Case $B$, in which the developer seeks an increase in density, the rejection by the community appears to have a more solid basis. This type of case undoubtedly represents a majority of the current disputes over dwelling type. Presumably, the increased density would have a direct and substantial impact upon community services. If we assume-and it is a hefty if-that this burden will not be offset by added revenues, ${ }^{259}$ then the community may insist, with a marked degree of persuasiveness, that it is entitled to deny the developer his request. A plausible defense does not in this case require the invocation of the ancient shibboleths of filth and disease, light and air; nor

258 In an early case, the Illinois Supreme Court stated that the evidence supporting the exclusion of apartments

is largely based on the undesirability of flats in a community like Lake

Bluff, and, as testified to by one of the experts, on "the fact that the apartment house tends to bring a class of people to the suburban town different from the typical suburban residents, and a class considered by the suburban residents, in the development of their property, as less desirable," and on other aesthetic reasons which have no relation to the public health, safety or welfare.

Bjork v. Safford, 333 Ill. 355, 359, 164 N.E. 699, 701 (1928).

259 See, e.g., Rodgers v. Village of Tarrytown, 302 N.Y. 115, 122, 96 N.E.2d

731, 733, 100 U.' PA. L. REv. 467 (1951), suggesting that the burden can be offset. 
does the municipality have to shift to the other end of the police power spectrum and plead "established character." It can point, with varying degrees of proof, to the increased burden on utilities, traffic, and schools that will result if the density is increased from four to twelve families per acre.

The issue of increased density and its burden on services has been debated in cases involving large lot zoning ${ }^{260}$ and trailer parks. ${ }^{261}$ In the case of large lot zoning, the change-in-density issue is the same as that posed by multiple-family dwellings. Its effectiveness as a fiscal weapon in that situation has not always withstood critical examination. ${ }^{262}$ Because large acreage zoning does not enjoy the aegis of decades of acceptance, ${ }^{263}$ the five-acre lot has occasioned more searching judicial review than has the resistance of communities to increased density due to apartments. In addition, the idyl of the large lot exurbanite will be attacked, not by some person of dubious origin seeking to build rental housing, but by none other than a potential singlefamily homeowner who wants to build a detached dwelling on a 10,000 square-foot lot in what was once the rural fringe, but now an integral part of the urban area. ${ }^{204}$ And once he succeeds, this same small-lot buyer who resented the "snob" zoning of Bull Valley Estates will not appreciate the irony of his cry five years later against a proposal to build apartments in what is now the Village of Bull Valley Vista.

One of the most troublesome aspects of the cost-revenue argument used to justify both large lot and single-family zoning is that it begs the question. It implies that each community has the right to reject increased density simply because development will require additional public services. Such a restrictive home-rule philosophy is now quite common. But the economic and social mobility and growth of American society is attributable in large part to the frontier psychology which insisted that the availability of public services follows the demand rather than controls it. Without this premise, we would never have

280 See cases cited in 106 U. PA. L. REv. 292 (1957). See also Haar, Zoning for Minimum Standards: The Wayne Tozenship Case, 66 HaRv. L. REV. 1051, 1058-59 (1953). Of the cases on large lot zoning, Norman Williams comments: "The intellectual level of most of these opinions is appalling." Williams, Planning Lare and the Supreme Court, 13 ZONING DIGEST 97, 109 n.100 (1961).

261 See, e.g., Town of Yorkville v. Fonk, 3 Wis. 2d 371, 88 N.W.2d 319 (1958), and the other cases cited in Note, 13 Syracuse L. REv. 125 (1961).

262 See note 201 supra.

263 For the history of large lot zoning see Crane, Progress in the Science of Zoning, 155 Annals, pt. 2, pp. 194, 197 (May, 1931).

264 In the Philadelphia suburban area, $76 \%$ of all zoned residential land is zoned for lots one-half acre in size or larger. Coke \& Liebman, Political Values and Population Density Control, 37 LAND ECoNomics 347, 348 (1961). Only a quarter century ago Edward Bassett doubted that lot sizes larger than one-third acre would obtain judicial acceptance. BASSET, ZoNING 87 (1936). 
crossed the Alleghenies. The early history of the United States shows a continuous, deeply-rooted policy of encouraging growth and expansion. If the Homestead Act had permitted settlement of the West only upon the consent of the existing residents, the Indians might have been happier, but it would be a much different country today.

This does not mean that unrestricted growth and expansion can be our policy today. Even in the century of manifest destiny, the national parks and forests were restricted to low-density development. But growth and expansion should be the rule, and restriction and exclusion the exception. Any community which wishes to retain lowdensity development should be required to show why, among all of the towns in the region, it deserves to be set aside as a low-density reservation. Perhaps it can point to drainage or transportation problems which would justify restrictive policies as a matter of sound regional planning; perhaps it cannot. But the tragic fact is that in most states today a community does not need to cite regional considerations to justify its restrictive policies on density because the courts have not required it.

If each separate community may plead an alleged strain on public services as a basis for rejection of greater density, then we have indeed repudiated those theses on which this continent was developed, and have returned full circle to a medieval society, granting exclusive corporate franchises based upon a municipal primogeniture. If each town's crowded schools, overtaxed sewers, or inadequate streets are sufficient bases for excluding a use of land which will increase the burden, then we have subscribed to the principle that what has been done is the legal justification for what shall be done. On this reasoning, the prudent school district must accept the pressure of heavier density, while the spendthrift district can plead inability to meet the added cost. The community which has enshrined its xenophobia in a "master plan" has demonstrated a skill in "one-upmanship" that will be the envy of its more lethargic municipal neighbors. ${ }^{265}$ The rural community can validily refuse to accept a share of the centrifugal explosion, ${ }^{266}$ but the municipality closer to the urban core which has come

265 See McBride \& Babcock, The Master Plan-A Statutory Prerequisite to a Zoning Ordinance?, 12 ZoNING Digest 353 (1960) ; Haar \& Mytelka, Planning and Zoning, 13 ZonING DIGEST 33 (1961); Doebele, Horse Sense About Zoning and the Master Plan, 13 Zoning Digest 209 (1961).

200 For an example of the latest exclusion technique, see Gruber v. Mayor of Township of Raritan, 39 N.J. 1, 186 A.2d 489 (1962), in which, on the advice of a planning consultant, the town rezoned a tract which was being developed with small houses to permit only industrial use, although there was grave doubt whether any industry would ever want to locate in the area. Compare Opgal, Inc. v. Burns, 20 Misc. 2d 803, 804, 807, 189 N.Y.S.2d 606, 609, 611 (Sup. Ct. 1959), aff'd, 10 App. Div. 2d 977, 201, N.Y.S.2d 831 (1960), aff'd, 9 N.Y.2d 661, 173 N.E.2d 50, 212 N.Y.S.2d 75 (1961). See also Ledermann, What the Home Builder Doesn't Like About Zoring, 13 ZoNING Digest 265 (1961). 
too late to the planning banquet may have no legal basis for refusal. ${ }^{207}$ In short, if inadequacy of local public services, without any consideration of the broader regional problems, is a defense to a petition for greater density, it will contribute to the already distorted pattern of metropolitan growth. ${ }^{288}$

The not unexpected answer of the beleaguered municipality to all this pondering is that it has been given a charter by the state legislature which authorizes it to make these decisions without a by-your-leave to anyone else. ${ }^{268}$ This, however, is not wholly true. Although the states have delegated decision-making authority in zoning as well as in many other areas to a multiplicity of governmental units, it is the courts, not the legislatures, which, by judicial acceptance of what can only be described as fantastic distortion of the concept of general welfare, ${ }^{270}$ have first sanctioned and then variously expanded the zoning technique. As the courts have enlarged the scope of the power over land use of the smallest governmental units, ${ }^{271}$ and have extended to each separate municipality the right to make its own decisions without regard to the impact on the greater community of

${ }^{267}$ See Haar, Wayne Tozonship: Zoning for Whom?-In Brief Reply, 67 Harv. L. REv. 986, 992 (1954).

268 For an example of the emphasis given by the courts to municipal rather than regional planning see the following quote from Judge (now Justice) Stewart's opinion in Valley View Village, Inc. v. Proffett, 221 F.2d 412, 418 (6th Cir., 1955):

Traditional concepts of zoning envision a municipality as a selfcontained community with its own residential, business and industrial areas. It is obvious that Valley View, Ohio, on the periphery of a large metropolitan center, is not such a self-contained community, but only an adventitious fragment of the economic and social whole. We cannot conclude as a matter of law that an ordinance which places all of the area of such a village into a residential district is per se arbitrary and unreasonable, with no substantial relation to the public health, safety, morals or general welfare. It would appear contrary to the very purposes of municipal planning to require a village such as Valley View to designate some of its area for business or industrial purposes without regard to the public need for business or industrial uses. The council of such a village should not be required to shut its eyes to the pattern of community life beyond the borders of the village itself. We think that it is not clearly arbitrary and unreasonable for a residential village to pass an ordinance preserving its residential character, so long as the business and industrial needs of its inhabitants are supplied by other accessible areas in the community at large. (1962).

260 See Crawford, Home Rule and Land Use Control, 13 W. Res. L. REv. 702

270 Mention must at least be made of Pennsylvania's great semantic debate over the meaning of the term "general welfare." See Bilbar Constr. Co. v. Easttown Township Bd. of Adjustment, $393 \mathrm{~Pa} .62,141$ A.2d 851 (1958); Appeal of Key Realty Co., 408 Pa. 98, 182 A.2d 187 (1962). This debate has emphasized the philosophical aspects of general welfare. The debate is concentrated on the word "welfare" rather than the word "general." See Craig, Zoning Law, 24 U. PITT. L. Rev. 303 (1962).

271 In Montana, the legislature has enacted, and the state supreme court has upheld, a statute allowing the formation of a planning and zoning district upon petition of $60 \%$ of the residents of any area forty acres in size or larger. See City of Missoula v. Missoula County, 139 Mont. 256, 362 P.2d 539 (1961); Doull v. Wohlschlager, 377 P.2d 758 (Mont. 1963). 
which it is a part, "general welfare" has become "limited welfare"limited to the interests of one municipality among hundreds. ${ }^{272}$ But Justice Sutherland properly foresaw "the possibility of cases where the general public interest would so far outweigh the interest of the municipality that the municipality would not be allowed to stand in the way." 273

If a community pleads that increased density will impose an undue burden, it might be useful for the courts to determine what burden will be created on the larger metropolitan area if the community does not permit this development. ${ }^{274}$ If a community pleads added costs, it may be fair to determine by whom those costs are really paid. If the community asserts its primacy as a detached dwelling suburb and points to other communities which, after all, are already marked by apartment development, it may be a reasonable retort that it is not the function of public control over private property to encourage highdensity ghettos. The courts should not sanction a rule of thumb by which a community having one-third or more of its land devoted to apartments cannot refuse others, but one with anything less than onethird may do so. ${ }^{275}$ Nor is it persuasive for a community which is part of a metropolitan area to plead the existence of a comprehensive plan ${ }^{276}$ which does not happen to contemplate the requested density.

272 Compare Lionshead Lake, Inc. v. Township of Wayne, 10 N.J. 165, 89 A.2d 693 (1952), appeal dismissed, 344 U.S. 919 (1953), with Borough of Creskill v. Borough of Dumont, 15 N.J. 238, 247, 104 A.2d 441, 445-46 (1954).

273 Village of Euclid v. Ambler Realty Co., 272 U.S. 365, 390 (1926). But see Bettman, The Decision of the Supreme Court of the United States in the Euclid Village Zoning Case, 1 U. CINC. L. REv. 184, 190 (1927). Bettman writes that this passage correctly states the conflict "not as one between the individual and the community, but rather as between different communities, different social groups or social interests . . . " However, he finds it "salutary and refreshing" that the court did not require the community "to merge its welfare completely in that of the surrounding region."

$274 \mathrm{On}$ the feasibility of a state zoning commission as a possible means of resolving density disputes, see Babcock, The Unhappy State of Zoning Administration in Illinois, 26 U. CEI. L. REV. 509, 538-40 (1959); Haar, Regionalism and Realism in Land-Use Planning, 105 U. PA. L. REv. 515, 533 (1957). See also Schaefer v. City of East Detroit, 360 Mich. 536, 541, 104 N.W.2d 390, 393 (1960) (Smith, J., dissenting).

275 In a conversation with one of the authors, a judge from one of the middlesized states remarked that he had deduced this "rule of thumb" from the opinions of his state's highest court.

276 The comprehensiveness required of a "comprehensive plan" is often minimal. For example, in Allin v. Zoning Comm'n, 186 A.2d 802, 804 (Conn. 1962), the court found that the town's comprehensive plan consisted of "the creation of small, scattered business districts" in an otherwise residential area. See also Marshall v. Salt Lake City, 105 Utah 111, 141 P.2d 704 (1943).

In a case in which the authors participated, a planning consultant, when asked about the village's comprehensive plan, testified that "the over-all comprehension of a land-use pattern was the intangible thing in the minds of the village officials."

The Pennsylvania Supreme Court seems to define comprehensiveness purely in terms of area-if a large area is rezoned there must have been a comprehensive plan. Compare Appeal of Key Realty Co., $408 \mathrm{~Pa} .98,101,182$ A.2d 187, 189 (1962), with French v. Zoning Bd. of Adjustment, $408 \mathrm{~Pa} .479,184$ A.2d 791 (1962). 
This approach, too, begs the touchy question of whether any plan for land use and public services can be a valid basis for decision-making when the plan was created by and for one one-thousandth of the total population of a metropolitan area. ${ }^{277}$ There are, for example, scores of communities in the Chicago metropolitan area, most of them shouldering each other like Christmas shoppers in a Marshall Field elevator. No rational system of jurisprudence can permit each of them to define the "general welfare" in its own image, anymore than the lone seeker after frozen lobster Newburg can dictate that the elevator shall proceed without stops to the seventh floor by closing his eyes, putting his fingers in his ears, and comprehensively planning that the elevator shall make no stops.

The weakness in the municipal defense-increased cost of services-to a proposal to increase density lies in the failure to recognize that the burdens of increased density do not rest solely upon each incorporated municipality, ${ }^{278}$ but upon the metropolitan area as a whole. Transportation, water, sanitary facilities, open space, and, indeed, schools are metropolitan issues on which rational decisions can be made only in a context that looks beyond political boundaries. Yet in zoning law, it is assumed that only the defending municipality has any interest in the contest with the developer. The dispute is viewed as a dialogue between two parties, in which the developer is pictured as a money-grubbing baron (as he may be) and the village as the exclusive repository of the public interest. It is high time that the courts showed a willingness to recognize that three parties are concerned with density-the developer, the municipality, and the metropolitan area as a whole. The developer may frequently be wrong, but the measure of his error should not be the often false premise that general welfare is only coextensive with the one community in which his development will be located.

This Article is not a call for metro, nor the expression of a futile hope that state legislatures will suddenly resist the power of the mu-

277 [L]and-use planning in any comprehensive sense really does not exist in our larger urban areas. What does exist is a complex game of chess among localities, each attempting to palm off the undesired applicants for space upon their neighboring communities. This is warfare, not planning.

Vernon, The Myth and Reality of Our Urban Problems 37-38 (1962).

278 While we have recognized traffic as a factor, it is not in itself entitled to too much weight since it is a problem in all but the most sheltered neighborhoods and is constantly getting worse.

A somewhat similar observation may safely be made with respect to schools. . .

We believe it unnecessary to pass upon the issue of whether the additional impact upon school population is a factor to be considered, since the increase would be de mintimtis under the evidence in this case.

LaSalle Nat'1 Bank v. Village of Skokie, 26 Ill. 2d 143, 146-47, 186 N.E.2d 46, 48 (1962). 
nicipal leagues. It is, however, a suggestion that the courts can and should reexamine the part they have played in this area of the law. If this sounds like a plea for untidy judicial activism, one answer is that judicial activism helped get us into this trap. Another reply could be that no community is going to give up part of its sovereignty over land use planning unless it sees that the suburbs must either hang together or hang separately.

What is needed and possible-even with the density assumptions in Case $B$-is a challenge by the courts of the old assumptions on the limits of municipal independence in planning in the bleak light of the social and economic interdependence of municipal units in urban America. ${ }^{279}$ It may be that in many cases the results will be the same; the interests of the community in resisting increased density may in many instances correspond with the interest of the larger metropolitan area. In some rare situations, the community may make a showing that it is carrying out a good-faith program of capital improvements and intends to phase in higher density over a reasonable period. ${ }^{280}$ But generally the only evident municipal objective is to freeze its present character. In this context, a judicial inquiry would force a reexamination of the principles of the 1920's which today may be false idols. Such an effort would surely better befit the bench than ex cathedra non sequiturs such as "apartment houses are not inherently benign." 281

\section{Prospects For the Future}

Is there the slightest chance that the courts will reappraise the legal basis for the popular distinction between multiple-family and detached dwellings? The willingness of many courts to accept novel zoning techniques such as design controls, ${ }^{282}$ amortization, ${ }^{283}$ floating

279 Would a limitation on the right of local governments to select housing types decrease the desirability of the suburbs for the well-to-do and foster a return to the city? Cf. Downs, Metropolitan Grozeth and Future Political Problems, 37 LAND ECoNomics 311, 316 (1961).

280 See, for a possible example, Josephs v. Town Bd., 24 Misc. 2d 366, 198 N.Y.S.2d 695 (1960). See the papers on Development Timing in AMERICAN SoC'Y of Planning Officials, Planning 1955, at 81-95.

281 Finale v. Borough of Hasbrouck Heights, 26 N.J. 320, 325, 139 A.2d 749, 752 (1958).

282 City of New Orleans v. Pergament, 198 La. 852, 5 So. 2d 129 (1941) ; Opinion of the Justices, 333 Mass. 773, 128 N.E.2d 563 (1955); State ex rel. Saveland Park Holding Corp. v. Wieland, 269 Wis. 262,69 N.W.2d 217, cert. denied, 350 U.S. 841 (1955).

283 City of Los Angeles v. Gage, 127 Cal. App. 2d 442, 274 P.2d 34 (1954); Grant v. Mayor of Baltimore, 212 Md. 301, 129 A.2d 363 (1957); Harbison v. City of Buffalo, 4 N.Y.2d 553, 152 N.E.2d 42, 176 N.Y.S.2d 598 (1958); City of Seattle v. Martin, 54 Wash. 2d 541, 342 P.2d 602 (1959). 
zones, ${ }^{284}$ and "contract zoning" 285 suggests that unless the planning profession has the visceral fortitude to challenge the narrow goals of its municipal clients, ${ }^{286}$ the judiciary is not likely to retrace forty years of law on its own. ${ }^{287}$ Yet in recent months a few small clouds have appeared on the zoning horizon which may forecast more serious judicial scrutiny of the traditional attitudes toward multiple-family development. One should not be overly optimistic, though, because the clouds take the form of a dissenting and a concurring opinion, and also because they did not arise in a dispute over multiple-family housing proposals. One case involved community policy on trailer parks, the other community policy on motels, both residential uses in a broad sense, but apparently distinguishable from apartments. ${ }^{288}$ However, in both cases the protest went deeper than the particular use involved. Both opinions reflect a suspicion by at least a minority of the supreme courts of two populous states that judicial acceptance of municipal land use practices should be reexamined, and that the public welfare in these cases may not necessarily be as general as some municipal councils choose to define it.

\section{A. Vickers v. Tozenship Comm.}

In Vickers $v$. Township Comm., ${ }^{289}$ the majority of the court held that a rural township, 23 square miles in area, could validly exclude all trailer parks from its boundaries.

284 DeMeo v. Zoning Comm'n, 148 Conn. 68, 167 A.2d 454 (1961) ; Huff v. Board of Zoning Appeals, 214 Md. 48, 133 A.2d 83 (1957) ; Rodgers v. Village of Tarrytown, 302 N.Y. 115,96 N.E.2d 731 (1951).

285 See, e.g., Church v. Town of Islip, 8 N.Y.2d 254, 168 N.E.2d 680 (1960); Herr v. City of St. Petersburg, 114 So. $2 d 171$ (Fla. 1959); Gladwyne Colony, Inc. v. Township of Lower Merion, 409 Pa. 441, 187 A.2d 549 (1963).

286 There is little evidence of such fortitude.

It is, in effect, the undeniable right of the general public to determine its own living environment even without regard to other considerations. Thus, local public opinion is paramount in the determination of proper locations for tall buildings.

Planning Dep't, Santa Anna, Cal., The Proper Place of Multi-Story StrucTURES IN AN URBAN Comaunity 12 (1961). See also the planning consultant's testimony quoted in Babcock, Mr. Commissioner, Are You Prepared for Crossexamination?, 3 Southwestern Legal Foundation, Institute on PlanNING and ZoNING 155, 164-67 (1962).

287 See Haar, Regionalism and Realism in Land-Use Planning, 105 U. PA. L. REv. 515, 530-31 (1957).

288 But see Long v. Norton Township, 327 Mich. 627, 42 N.W.2d 764 (1950), and People ex rel. Grommon v. Hedgcock, 106 Colo. 300, 104 P.2d 607 (1940), holding motels to be indistinguishable from multiple-family dwellings. See also Trailer Towns, Inc. v. Board of Adjustment, 144 Colo. 340, 356 P.2d 251 (1960); Lescault v. Zoning Bd. of Review, 162 A.2d 807 (R.I. 1960).

28937 N.J. 232, 181 A.2d 129 (1962). Compare Gust v. Township of Canton, 342 Mich. 436,70 N.W.2d 772 (1955). 
If through foresight a municipality is able to anticipate the adverse effects of particular uses and its resulting actions are reasonable, it should be permitted to develop without the burdens of such uses. 290

Few judicial expressions so succinctly embrace so many unexamined assumptions: is it "foresight" or luck; what are the "adverse effects" of trailer parks; in what context is the reasonableness of the municipality's "resulting actions" to be judged?

Judge Hall, who by no means can be described as unfriendly to community planning, ${ }^{291}$ noted at the beginning of his dissent ${ }^{292}$ that the trailer park was "a symbol" ${ }^{293}$ of a more fundamental issue-the freedom of municipalities to erect "exclusionary walls on their boundaries." 204 For our purposes, however, it is Judge Hall's challenge to the role of the judiciary in these land use disputes that is most significant. He notes that the majority opinion is grounded on the presumption of the validity of municipal action, and the requirement that the proof overcome that presumption beyond debate. ${ }^{295}$ The majority, he says, applies these principles in a perfunctory manner, ${ }^{206}$ allowing the judicial process to go far off the mark. ${ }^{297}$

Proper judicial review to me can be nothing less than an objective, realistic consideration of the setting-the evils or conditions sought to be remedied, a full and comparative appraisal of the public interest involved and the private rights affected, both from the local and broader aspects, and a thorough weighing of all factors, with government entitled to win if the scales are at least balanced or even a little less so. ${ }^{298}$

290 Vickers v. Township Comm., 37 N.J. 232, 249, 181 A.2d 129, 138 (1962). Contra, Dequindre Dev. Co. v. Charter Township of Warren, 359 Mich. 634, 103 N.W.2d 600 (1960).

201 See Hall, One Judge Looks at Land Use Regulation in 1961, in AMERICAN Society of Planning Officials, Planning 1961, at 6.

292 Judge Schettino concurred in the dissenting opinion.

29337 N.J. at 253,181 A.2d at 149 (dissenting opinion).

294 Id. at 252, 181 A.2d at 140 . See also Bilbar Constr. Co. v. Easttown Township Bd. of Adjustment, 393 Pa. 62, 90, 141 A.2d 851, 865 (1958) (Beli, J., dissenting):

Moreover, such an unconstitutional concept and application of the police power would likewise apply to every suburban area, district, township and county and would stifle and in reality effectually block the expansion of our country's rapidly growing population into any suburban township or county, or would herd the poor and medium income people into specified areas and effectually and intentionally limit parts or all of a county to the rich or well-to-do. Such an intentional and exclusionary interdiction is contrary to our constitutional guarantees and to the American Way of Life.

29537 N.J. at 256,181 A.2d at 142.

296 Id. at 258,181 A.2d at 143.

297 Id. at 257,181 A.2d at 142 .

208 Id. at 260, 181 A.2d at 144. But see Smith, J., dissenting, in Schaefer v. City of East Detroit, 360 Mich.' 536, 541, 104 N.W.2d 390, 393 (1960). Judge Smith argued that the Michigan court "misconceived its appellate function" by exercising too strict judicial review. Cf. Vulcan Materials Co. v. Griffith, 215 Ga. 811, 114 S.E.2d 29 $(1960)$. 
Under the majority's interpretation of the general welfare, Judge Hall observed, it is hard to conceive of any local action which would not be debatable. ${ }^{299}$

Certainly "general welfare" does not automatically mean whatever the municipality says it does, regardless of who is hurt and how much . . . . The . . "general welfare" transcends the artificial limits of political subdivisions and cannot embrace merely narrow local desires. ${ }^{300}$

Judge Hall did not overlook the possibility that there was a substantial disparity between the facts which may have explained, if not validated, judicial and social attitudes in a past era and the facts of today.

"Community distaste for trailer dwellers personally developed at a time when the trailerites were often considered footloose, nomadic people unlikely to make positive contribution to community life. . . Mobile homes, however, can no longer be said to be inhabited primarily by migratory paupers . . . " 301

If "tenement" is substituted for "trailer," we have the unmistakable attitude of the courts toward multiple-family dwellings in the 1920's.

\section{B. Ward v. Village of Skokie}

Six months later, in Ward $v$. Village of Skokie, ${ }^{302}$ Judge Klingbiel $^{303}$ of the Illinois Supreme Court took an opportunity to protest the unquestioning judicial acceptance of $a d$ hoc treatment by local legislatures of another unpopular residential use ${ }^{304}$-in this case a motel. Under the Skokie zoning ordinance, motels were not a permitted use in any district. In some districts they could be allowed as a special use upon approval of the local legislature. The plaintiff's petition for

29937 N. J. at 260,181 A.2d at 144.

300 Id. at 262-63, 181 A.2d at 145-46 Compare Faught, Zoning Under Changing Conditions in Pennsylvania, 10 U. PITT. L. REv. 311, 314 (1949): "There is hardly another field of law in which local characteristics, customs and standards are as important as they are in zoning. Here we are close to fundamental democracy." (1962).

30137 N.J. at 268, 181 A.2d at 148-49, quoting from Note, 71 Y ALE L.J. 702, 703

30226 I1l. $2 d$ 415, 186 N.E.2d 529 (1962).

303 Judge House concurred in Judge Klingbiel's concurring opinion. Judge House also filed a brief dissenting opinion-in which Judge Klingbiel concurred-in Camboni's, Inc. v. County of DuPage, 26 IIl. $2 \mathrm{~d} 427,433,187$ N.E.2d 212, 216 (1962), expressing agreement with the same principles. Judge House had dissented when the Illinois court originally approved the special use technique. Kotrich v. County of DuPage, 19 I11. 2d 181, 189, 166 N.E.2d 601, 606 (1960) (dissenting opinion); see Hartung v. Village of Skokie, 22 Ill. 2d 485, 177 N.E.2d 328 (1961).

304 See Babcock, The Unhappy State of Zoning Administration in Illinois, 26 U. ChI. L. REv. 509, 521 (1959). 
a special use permit was denied by the local legislature, although the plan commission had found compliance with the standards in the ordinance and had recommended that the petition be granted. The majority of the Illinois Supreme Court held that the refusal to authorize the special use was unreasonable, and hence invalid, because the site for the proposed motel was located on a major highway in a neighborhood dominated by commercial uses. ${ }^{305}$ The majority did not, however, question the validity of the special use concept, which had previously been upheld by the Illinois court. ${ }^{306}$

Judge Klingbiel did not quarrel with the result, but felt that the court should have reexamined the validity of the whole concept of special uses. ${ }^{307}$ The constitutionality of such a technique, said Judge Klingbiel, is open to serious question:

The granting of special permits of this kind is an administrative or quasi-judicial function which can be exercised only in accordance with prescribed rules or standards. Ordinances providing for an unrestricted power to approve or reject are in violation of basic constitutional protections and cannot be sustained. ${ }^{308}$

To the argument that special use permits are granted by the legislative body, Judge Klingbiel replied:

It is not a part of the legislative function to grant permits, make special exceptions, or decide particular cases. Such activities are not legislative but administrative, quasi-judicial, or judicial in character. To place them in the hands of legislative bodies, whose acts as such are not judicially reviewable, is to open the door completely to arbitrary government. I need not dwell at length on the obvious opportunity this affords for special privilege, for the granting of favors to political friends or financial benefactors, for the withholding of permits from those not in the good graces of the authorities, and so on. The rule is familiar enough that courts may not inquire into the motives or reasons on which the legislative body acted..$^{309}$

305 Ward v. Village of Skokie, 26 Ill. 2d 415, 418, 186 N.E.2d 529, 530 (1962). 306 Kotrich v. County of DuPage, 19 Ill. 2d 181, 166 N.E.2d 601 (1960).

307 See Green, Are "Special Use" Procedures in Trouble?, 12 ZonING Digest 73 (1960); Haar \& Hering, The Lower Gwymned Township Case: Too Flexible Zoning or an Inflexible Judiciary, 74 HARV. I. REv. 1552 (1961); Bair, Zoning-A Mad Tea-Party?, 12 ZoNING DIGEST 33 (1960).

308 Ward v. Village of Skokie, 26 Ill. 2d 415, 422, 186 N.E.2d 529, 532 (1962). See also Pierson Trapp Co. v. Peak, 340 S.W.2d 456 (Ky. 1960); McCauley v. Albert E. Briede \& Son, 231 La. 35, 47-48, 90 So. 2d 78, 82-83 (1956); Rockhill v. Chesterfield Township, 23 N.J. 117, 128 A.2d 473 (1957); Eves v. Zoning Bd. of Adjustment, $401 \mathrm{~Pa}$. 211, 164 A.2d 7 (1960); Kohnberg v. Murdock, 6 N.Y.2d 937, 161 N.E.2d 217, 218, 190 N.Y.S.2d 1005, 1006 (1959) (dissenting opinion). People v. Perez, 29 Cal. Rptr. 781 (App. Dept., Super. Ct. 1963).

30026 III. $2 d$ at 424,186 N.E.2d at 533. 
Judge Klingbiel then made a plea for greater judicial surveillance of zoning techniques-a call reflecting the same concern that appeared in Judge Hall's dissent:

It seems to me that the vital issues involved here have not been adequately faced, let alone decided. With nothing more than a reference to the special permit provisions, the court in the present case proceeds to consider the propriety of the particular denial, on the necessarily implicit assumption that the ordinance itself is unobjectionable. . . .

The result of course is that these arbitrary provisions remain undisturbed, obliging the next unfortunate owner to fight out the question of constitutional reasonableness as to his particular property, and so on as to every person who is denied the right to put up a motel. ${ }^{310}$

\section{Conclusion}

If it be observed that two judicial swallows do not make a jurisprudential summer, it seems fair to rejoin that these two voices are a vast and clamorous flock when compared to the silence from the legislative branch. No legislator, whether at the state or local level, can be expected to initiate, much less carry through to its challenging conclusions, a serious reexamination of the premises on which the present fractured system of decision-making over private land use has been based.

As in the passionate areas of school segregation and reapportionment, legislative action in the agitated field of private land use will probably be forthcoming only when the bench challenges the current posture of the law. Courts cannot plan, but by challenging the present construction of "general welfare" and reexamining the "principles" of

31026 IIl. $2 d$ at 426,186 N.E.2d at 534. The authors do not imply that Judge Hall or Judge Klingbiel share all or any of the opinions expressed in this Article, or that they would feel that apartments are basically indistinguishable from motels and trailer parks. However, the following quote from a recent speech by Judge Hall may be significant:

In any well populated area, there is a necessity for a great many legitimate land uses which many people find objectionable for various reasons. We know we must have them somewhere, but we say they should be in some other town, not in ours. So we exclude them and so do lots of other places. Where can they locate? I refer to such things as the so-called nuisance industries, private, tax-exempt religious, educational and philanthropic institutions, even trailer parks and perhaps apartment houses. Some students of the problem have suggested that exclusion from a particular municipality should only be sustained if there is some other entirely suitable and available location in the general area where the tuse is permitted and where the municipal authorities have agreed to accept it. I do not suggest this ought to be the answer, but merely mention it to stimulate your thinking with respect to a problem that I suspect will have to be squarely met soon.

Hall, Planning and Zoning-The Positive Tools of Government, New Jersey Municipalities, Jan. 1963, pp. 5, 9. 
another era, they can compel communities to redefine their planning goals and reevaluate their validity. With the current boom in multiplefamily housing construction, this reappraisal is urgently needed in the field of dwelling type and density. Until the courts cease to use old phrases and slogans as a substitute for inquiry, there is no reason to expect that the suburbs will volunteer a reassessment of their opposition to multiple-family dwellings. Although modern courts hesitate to talk of pestilence, fire, and immorality as did their brothers of forty years ago, they continue to assume the validity of the segregation of housing types, without contributing to a reasonable solution of the dispute. What is called for is a judicial inquiry on the following questions: (1) By what standards should the classification of dwelling types by local government be judged? (2) If the segregation of dwelling types can no longer be justified under the rubrics of "health, safety, and morals," then what is the nature of the "general welfare" by which the enshrinement of the detached dwelling is yalidated? It may be appropriate to join this latter question with the reminder that the police power was not designed as a cardinal principle, but as a limitation on the primary right of the owner of property to use his property as he sees fit. Unless the developer's use will have a demonstrable and adverse impact upon the general welfare, the police power should not come into play. If, in the context of a housing dispute, there is no valid public interest in segregating multiple-family dwellings, there is no basis under our system for saying nay to these new housing demands.

This line of inquiry inevitably leads to the more troublesome question: (3) Assuming that there is a public interest in segregating dwellings by type, who shall participate in the formulation of that public interest-each separate suburb, irrespective of its pipsqueak size, amoebic shape, and historical origins, or the entire metropolitan community? In short, does it make legal, economic, or social sense to speak of the "general welfare" of one village of 5,000 population which is set in a metropolitan area of 200 similarly incorporated communities?

There may be valid grounds for isolating the single-family home; we are only suggesting that, in the face of the multiple-family dwelling boom, the question is sufficiently urgent to merit more serious analysis than it has been given. In the current political posture, neither the communities nor the state legislatures will undertake this disquieting job unless the courts compel them to do so. 